\title{
SARS 講演会記録
}

\author{
会 期 平成 15 年 6 月 2 日（月曜日）午後 $1: 00 \sim 4: 00$ \\ 会 場 日比谷公会堂（東京都千代田区日比谷公園 1-3) \\ 司 会 木村哲 (国立国際医療センターエイズ治療研究開発センター) \\ 岩本 愛吉 (東京大学医科学研究所先端医療研究センター感染症分野)
}

\author{
挨 拶 \\ 日本感染症学会/日本環境感染学会理事長 \\ 木村哲
}

木村でございます. 宜しくお願い致します. 本日は week day でもあり，色々お仕事がお忙しい事と存じますが， この会にご出席賜りましてありがとうございます.ご存知のように SARS が出ましてから半年足らずでございます が, これまでの間に，およそ 750 名の死者を出し，感染者は 8,200 8,300 名ということでございまして，未だに猛 威を奮っております．幸いなことに多少の制圧の動きが聞かれておりますけれど，そのような時にこそ，人の動き もまた活発になりはじめますので, 日本にも持ち込まれるということが, 今後益々予想されてくるわけで, 気持ち を引き締めてその対応を考えていかなくてはなりません. SARS は感染症と致しましても非常に感染力が強く, ま た進行が早く重症度が高いということで, 感染症学会としても大きなテーマであり課題であります. また, ご存知 のとおり院内感染が非常に起こりやすいことから環境感染学会としてもその対応を考えなくてはなりません.たま たま両方の理事長を仰せつかっておりますので, 会員の皆様方になるべく最新の正しい情報をお伝えして今後の診 療あるいは感染対策に役立てて頂きたいと考えまして, この会を開催させて頂きました. 今日は, 厚生労働省, 国 立感染症研究所, 国立国際医療センター, 杏林大学から SARSについてのエキスパートにお願い致しました. 内容・ 企画につきましては，座長の岩本愛吉先生に大変ご苦労頂きました． 3 時間でありますが，有益にお過ごし頂きま すよう宜しくお願い致します。 


\title{
SARS と感染症法 行政対応と課題
}

\author{
厚生労働省健康局結核感染症課感染症情報管理室
}

加 地 祥 文

\section{(スライド 1)}

ご紹介頂きました厚生労働省感染症情報管理室長の 加地でございます.今日は行政的な対応の観点からご 説明させて頂きます.

(スライド 2)

本日のトピックとして，1 点目として SARS に関す る新感染症としての取り扱いの経緯, 考え方, 2 点目と して接触者調査の問題点. これは先般, 台湾人医師の ツアーがあり, その時の各自治体の接触者調査の色々 な混乱点, 問題点が明らかになった点であります. 3 点目は情報公開の問題点.これも接触者調査とも非常 に関連しておりますし，また，一般的な疑い例，可能 性例の報告があった場合での情報公開の点に言及した いと思います. それから水際の検疫の問題点. これま での検疫のやり方と SARSに対する水際の対策の問 題点. そして最後に院内感染対策といったところでご ざいます。

(スライド 3)

まず，新感染症としての取り扱いについてでござい ます.これは一般的な名称ではなく，あくまでも感染 症法, 法律に規程をされている新感染症というものの 取り扱いでございますが，法律の条文の中に，未知の 病原体による新たな感染症に対する法的な枠組みとい うことで,これは平成 11 年伝染病子防法が改正され感 染症法になったときに, 新感染症という条文（カテゴ リー）が設けられました．新しい感染症という名前の 付かない状況のところで，国内あるいは世界のどこか で新しい疾病が発生しているというような状態の時, まだ病原体がわからない, 治療法がわからない, 感染 ルートもわからないといった段階での公衆衛生上での 対策をとるための一つのツールとして，新感染症とい う条文が設けられております。法律に馴染みのない方 には理解しにくく, 説明が難しいのですが, 新感染症 というのは，まったくのもやもやした状態の段階とあ る程度知見が集積されて, 前もって対応することが決 められるような状態，マニュアル化できるような状態 になった場合，というように2段階に分けられます。
一つは新感染症（個別の対応）でございます，もう一 つは, 例えば入院勧告, 健康診断を含めて政令によっ て指定をできる段階.この二つの段階があります。そ れから, 指定感染症というのは病原体が既知となった 場合, すでに病原体が分かってきた段階になって政令 で指定をした感染症で，なおかつ別の政令でございま すが，例えば先ほど申し上げました入院勧告や健康診 断や消毒であるとか, こういった事を 1 類から 4 類の 感染症の中から自由にオプションとして政令で指定し ていくというのがこの段階であります。そして新感染 症の政令, あるいは指定感染症の政令, というのは飽 くまでも 1 年間以内という時限的な措置でありますの で, 当然, 1 年を過ぎる前に公的に法律で 1 類から 4 類 感染症に位置付けるという法律改正をするか，あるい はこの政令を廃止するというような形になります。い ずれにしてもここからここまでは，とにかく 1 年間の 限定付でその 1 年間の中で法律にもっていかなくては ならないのが, 新感染症の特徴でございます.

(スライド 4)

これを見ていただきますと，これは今回新感染症に このSARSを取り扱いましょうというような事を全 国の自治体，医療機関に説明をした段階で作った資料 ですが, 新感染症がもともとどういう病気かわからな いので個別の対応を取るようになっています.

(スライド 5)

つまり新感染症の所見のある方，あるいは可能性例 を含んだ方が医師に受診し，医師が届出をしてきます. 新感染症の場合は, 感染症法の 12 条で医師に届出の義 務がかかります．保健所に届出をしたものが知事から 厚生労働省へ報告があります.ただこの病気は新感染 症ということで実態が分らないので, 厚生労働省の感 染症分科会（審議会）の中にSARS 対策専門委員会と いうものを設けています。実際にはここで報告があ がってきたものを判定することになります．今日も判 定委員会を開催して 4 例報告があった疑い例について は，いずれも SARSではないという判断になりまし た。一方で, 都道府県知事はこのような報告があった 
場合，この患者さんに対して入院，健康診断等の勧告 をすることができます。ただ，都道府県知事は入院勧 告をしょうとする場合は, 前もって厚生労働省大臣に 通報しなくてはなりません，通報を受けた厚生労働省 大臣は指導助言を都道府県知事に行いますが，前もっ て感染症分科会の意見を聞くことになっています，知 事がこの患者さんを入院させたい場合，厚生労働省大 臣に通報して，感染症分科会の意見を聞き，勧告を出 すことになります。また，この家族の健康診断を行な おうと思った場合も通報して意見を聞いた上で行な う，というょうな一つ一つの個別の対応をすべてこの 審議会の意見を聞いた上で措置をしていくいうのが新 感染症に対応の部分です．ちょっと戻りますがこの部 分です. (スライド4)これが政令指定されますと，この 部分が無くなって都道府県知事が個別の通報をしなく ても, 委員会の意見を聞かなくても, 実際に入院勧告, 健康診断を行えることになります. (スライド4) もう 一度戻りますと, 指定感染症になっても同じょうにこ の部分が無くなります，ただ，誤解の無いように申し 上げますが，ここの部分は現在もありますし，今後も 国の責務として都道府県知事に対する技術的な指導助 言というのが, 厚生労働省としての責務として感染症 法に婳われています。従いまして, 個別の事例で報告 があがったものについては, SARS 対策専門委員会で やはり判定をしていく，あるいは個別の相談にはここ で専門家の意見を聞いたうえで技術的助言をしてい く,ということは指定感染症になってもあるいは新感 染症の政令指定がされた上でも，これは変わらないと いうこと

でございます.現時点では,このような枠組みで行なっ ております。

(スライド 6)

これはよくご質問があるのですが, 現在, 医療機関 からの届出は疑い例も含めたものを届けて頂いており ます.つまり $38^{\circ} \mathrm{C}$ 以上の発熱と呼吸器症状, 渡航歴あ るいはSARSの患者さんとの濃厚な接触歴があるこ と.ここが疑い例となります。その中で肺炎症状を呈 するという状態が付け加わりますと可能性例（probable case）となります． 新感染症の所見を有する者は 行政的にここまでをいいます.つまり可能性例であれ ば都道府県知事は, 先ほどのここですが, 入院勧告を 出してこの可能性例を含む患者さんに入院していただ くことができます。そして入院して頂いた場合には, それは公費 (4 分の 1 が自治体, 4 分の 3 が国) で入院
費用を持ちます．健康診断についても公費で賄うとい うところが，ここの肝心なところで，可能性例という ところに入った場合に，新感染症法の所見を有する者

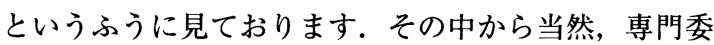
員会で確定する場合も含まれておりますが，逆に除外 されたとしても，入院勧告をした場合には公費でもつ ことになり，この可能性例であっても公費負担が出来 るということであります，現在，疑い例報告と可能性 例を報告して頂いておりますが，現時点で PCR，抗体 検査, ウイルス分離というような確定診断の方法がま だ実際には golden ruleにはなっておりません.従いま して，ここで言うように抗体検査でプラス，あるいは ウイルス分離がプラスとなった場合には，コロナウイ ルス感染を証明することが出来ます．また，逆に PCR でマイナスであっても，あるいはウイルス分離でマイ ナスであっても, コロナウイルスの感染を否定するこ とはできない，というような不確定な部分がまだあり ます.ということで先ほどの SARS であるかないかを 最終的に判定するのは, このSARS 対策専門委員会で 決定をしていくしかないのではと思っております.

(スライド 7)

次に, 接触者調査の問題点についてですが, これに ついては今回図らずも台湾医師のッアー一行が複数の 府県市をまたがって旅行されたことで，実際に自治体 の方々には接触者調査について多大なご苦労があった と聞いております，その中で，やはり問題となったの は, 公表の問題と絡みますがハイリスク接触者をどこ まで特定できるかということでございました。これは 例えば結核の接触者調査に比べますと，このSARS については時間的余裕がなく, まずホテルの宿泊者に ついては分るところから調べるといった点も若干ござ いました，そのようなことから最初からハイリスクと ローリスクという同心円上の調査が systematic に行 なわれたという訳ではなく, むしろ時間との戦い, 競 争ということでスタートしたというところがありま すそそれから，また国に対する批判として一番大きい のが疫学調査の手法について明確ではないということ が言われています．例えば，閉鎖空間というのをどう みるのか.フェリーに乗っていた人たちは閉鎖空間と してのハイリスク接触者になるのかあるいはならない のか. それから例えばロープウェーに乗っていた場合 はどうなのか. それからホテルでいえば同一フロアー に宿泊した人と別のフロアーに宿泊した人と, どうい うふうに考えるのか. そういった問題が具体的に調べ 
てくると特定が難しくなった．私どもの方から言いま したのは, ッアーの同行者が一番のハイリスク接触者 であろう, 次が長時間同じバス（閉鎖空間）に乗った ドライバー，それから次がホテルでのお世話をされた 方といったかたちで同心円上で考えていけばいいので はないか. 冷静になって考えれば皆さんそのように考 えていた訳ですが，実際になると時間に追われるよう な中では，なかなか整理が出来ない場面がございまし た.

\section{(スライド 8)}

それから非常に大きな問題として, 情報公開と言う ことで, 今の接触者調查との関連で行けば接触者を特 定できない施設については, 観光地であるので現在 色々な場所に居住されおり，一人一人にあたっていて は時間的にかかってしまう。 それから接触場所の特定 をする場合, 今回は不幸にも外国人旅行者であったと いうことと，ッアーコンダクターも既に日本にはいな かったということで, 日程や立寄り先の特定をするこ とが非常に難しかった。例えばレストランのような場 合，日本国内の居住者であれば，どのテーブルに座っ て食事をしたということが分れば，そこの接触者調查 が特定されて来るので, ある程度限定できるのですが, お昼を食べただけであれば，そこでどのような接触が あったか分らない，ということで自治体も苦労されて 結局は営業者の方に了解を得た上でレストラン名を公 表するというようなことになった訳です. 当然, ホテ ルによっては多くの宿泊者を調査しなくてはならない ので，時間的制約もあったというようなことでござい ます。そのようなことから，ここで言う接触場所の公 表と営業者の経済的損失，これを言葉を変えれば公衆 衛生と国民が受任できる範囲，こういったもののト レードオフをどのような線で引けるのかということ を, 自治体からはこの基準を示してほしいというょう なお話もございますが, 私どもの申し上げております のは, 一つ一つが応用問題でありますので, 絶対にこ ちらがいつでもこの基準でいけるというものがないの ではないかとも思います。一般市民への情報の提供と プライバシー保護の接点で，一般市民の方からも，早 く患者の氏名を公表するようにとか，ホテル名を公表 するようにというような苦情も沢山寄せられました。 そこで個人的プライバシーを，どこで妥協点を見い出 すのかということもあり，情報公開の問題点というの は感染症法の改正の審議会の中でも引き続き議論をし ていかなくてはならないと思っております。

\section{(スライド 9)}

感染症という明らかに潜伏期間がある病気に対し て, 水際での検疫というものが, 現在のような飛行機 で移動するような旅行手段になったために，これまで やってきた検疫のスタイルの問題が明らかになってき ております，従来であれば，通常，船で移動するとい うことを前提として構築された検疫法, これが飛行機 で移動するということまで入ってきますと，単純に通 過点, 点ですね, それこそ検疫所の前を通るのは 5 分 か 10 分, 現在は体温測定を行なっているので, それで も 5 分, 10 分の時間しかない. その中で, どのように 検疫をやっていくか，自ずから限界があります。そう 言う意味では水際行政，検疫と国内での連携をどのよ うに形作るかが課題となっております。現在は法的根 拠はございませんが，台湾あるいは中国から来られる 方で医療関係者で 10 日以内に SARS 患者を診た，あ るいは看護した，同居している人については質問票に チェックをして頂き，そのチェックの何れかの項目に 該当する場合は，イレギュラーではありますが，毎日 2 回体温測定をしていただき，厚生労働省へ連絡を入 れて頂くことをしております。その方が日本を出国さ れるまで一応どこにいて体温が何度あるのかをフォ ローしております.しかし,これは極めてイレギュラー なケースであります. 5 月 19 日から始めましたが既に 10 人以上いらしゃいます. 幸いに体温等については異 常はありません.

\section{(スライド 10)}

院内感染対策については, 中国, 台湾, シンガポー ル，また今トロントで再現しております SARSをみま すと, 問題が拡大するのは, やはり院内感染でありま す. 患者さん自身も医療関係者が 9 割, 8 割と言われて います。それから濃厚な接触をした同居者ということ になりますので，このSARS の問題を考える場合，一 つはもともとの感染源がどこにあるのかということが 非常に重要だと言えます，もうひとつ，どうしても重 要なことは我が国でも院内感染対策をどうするのかと いうことではないかと思っております．まず一つは一 次医療機関，つまり最寄りの医療機関と保健所には直 接行くのではなく, 前もって必ず電話でご相談いただ くことを基本としております.その段階で，医療機関 では感染症対策が不十分であると判断されたら，保健 所と連携をとり，診察医療機関を決めていただくこと になります．例えば感染症の対策の出来た医療機関に 行っていただく，そしてもう一つは，肺炎症状を呈す 
るような可能性例以上の場合は, 特定の感染症指定医 療機関に入院をしていただくようなことを，連携を上 手くとっていただくようなことが非常に重要だと思っ ております。

最後に，これまでの院内感染対策にない，こういっ たウイルスによる院内感染をどのように防止していく かについては，やはりこれまで通りの院内感染対策で
はなく, 別の視点, これから別の先生方がお話されま すが，ベトナム，中国などの院内感染対策を参考にし て，もう一度，見直しを図る必要があるのではないか と思っております。

本日，用意致しました話題については以上でござい ます.ありがとうございました. 
スライド 1

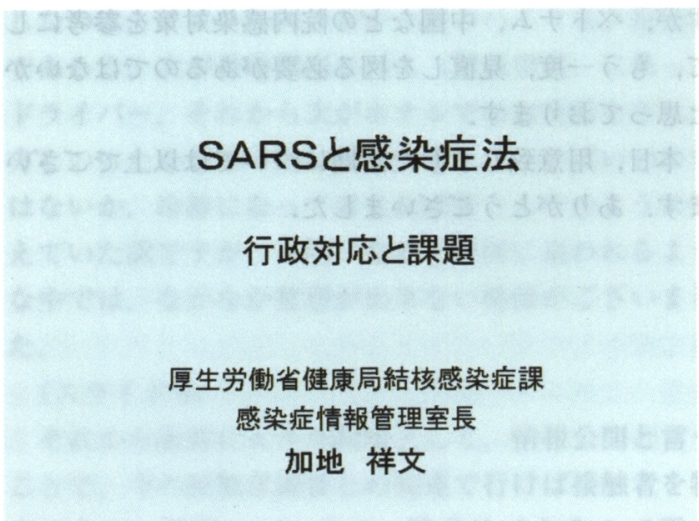

スライド 2

\section{本日のトピック}

- 新感染症としての取り扱い

- 接触者調査の問題点

- 情報公開の問題点

・ 水際の検疫の問題点

- 院内感染対策
スライド 4

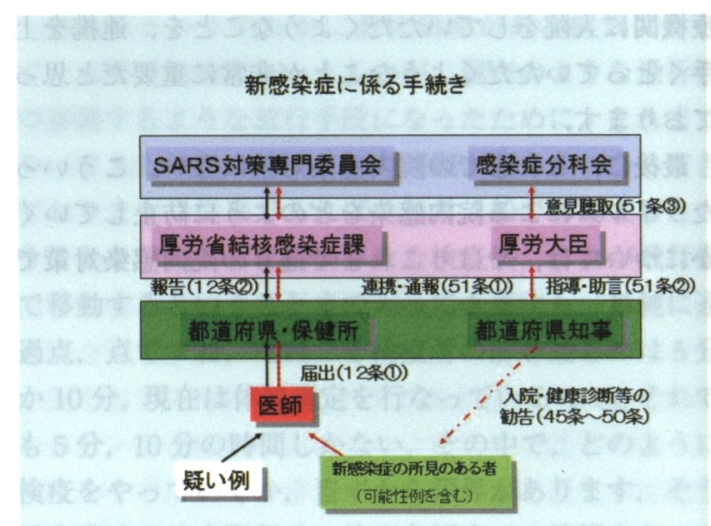

スライド 5

\section{SARSに関するWHO報告基準と新感染症の通報の関係}

\section{新感染症としての取り扱い}

-未知の病原体による新たな感染症に対す る法的な枠組み

- 新感染症 (個別の対応)

- 新感染症(政令による指定)

- 指定感染症 (政令指定)

- 法律での位置づけ(1類から4類感染症)

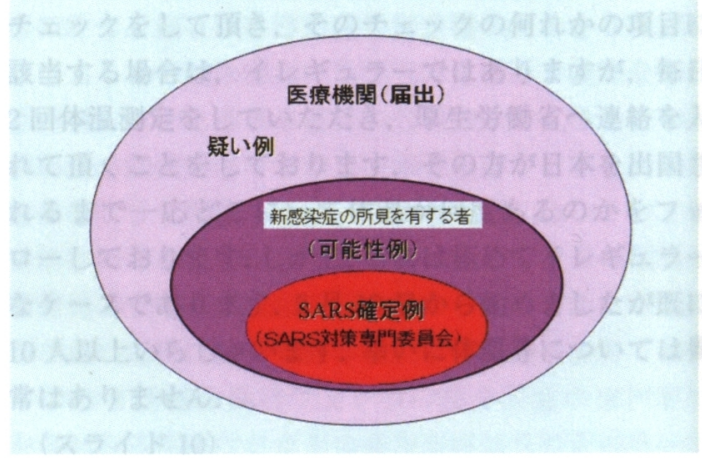

スライド 6

SARSウイルス検查

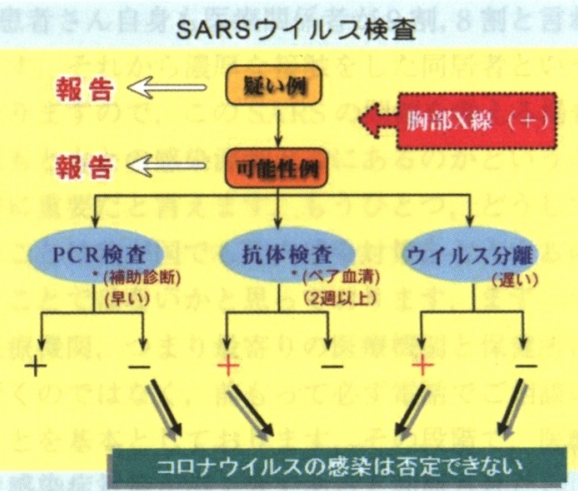


接触者調査の問題点

・ハイリスク接触者の特定

・ ローリスク接触者の調査

\section{水際の検疫の問題点}

- 通過点での検疫の限界

- 水際行政と国内行政との連携の問題
スライド 8

情報公開の問題点

- 接触者調查と接触場所の特定

- 接触者調査の時間的な制約

- 接触場所の公表と嫦業者の経済的損失

・一般市民への情報の提供とプライバシー 保護の接点
スライド 10

\section{院内感染対策}

-1次医療機関と保健所 (トリアージ)

- 診察医療機関と入院施設

- 新たな院内感染対策の必要性 


\section{SARS アウトブレーク}

国立感染症研究所感染症情報センター

岡 部 信 彦

\section{（スライド 1$)$}

国立感染症研究所の岡部信彦と申します.どうぞ宜 しくお願い致します.

木村先生から SARS の専門家が次々と話をすると いうことでしたが,この病気は専門家がおりませんで, にわか専門家ばかりです．ただ集中してこのところこ れに取りかからなくてはいけないという意味での専門 家としてご紹介したいと思います.

(スライド 2)

最近, 新興感染症, 再興感染症など, 色々な感染症 の問題が次々に話題となっておりますが, かつてと 違ってある一カ所で出た病気がローカルな病気で留ま る事なく拡大の可能性が高まっています.つまり, 人, 物, が大量, 短時間で移動していくのが現代ですから, 病原体の移動するのもまったく同様であるというとこ ろに新たな問題点があります.

スライドではいわゆる狂牛病を例に出しております が, その他香港におけるトリ型のインフルエンザ, 或 いはマレーシアにおける急性脳炎ニッパウイルスの発 見など，今まで動物だけがもっていた，或いは動物だ けの病気であった病原体が何らかのきっかけで人間の 方にやってきて, 人間にとっては今まで知らなかった 病気を発症するような例はこれまでも幾つかあげられ ます。そういった様な状況下の現代では新しい感染症 に対する警戒が続けられています。

(スライド 3)

SARS は，今年になって急に起こった訳ではありま せん. 昨年の 11 月頃から中国の広東省では, 非定型性 肺炎が多発していました。 今年の 2 月までに約 300 例 が発症, 5 名が亡くなっているという報告がありまし たが, 中国当局は剖検例からクラミジア肺炎であると 発表しておりました. 次いで, 香港に住んでいた人(親 子）が広東省の近くである福健省に行って帅ってきて から, 急性肺炎になり 2 人からトリ型のインフルエン ザが分離されたということがありました，お父さんは 亡くなっています. 1997 年に香港においてトリ型イン フルエンザに 18 名が感染して 6 名死亡という事例が
ありました，その時は，ヒト一ヒトの感染はなく，ト リからヒトへの直接の感染でした. 今回, 97 年以来, 初めてヒトからトリ型インフルエンザ $\mathrm{H}_{5} \mathrm{~N}_{1}$ が出た事 は今度こそヒト一ヒトの感染となり, 新型インフルエ ンザとして登場, つまり pandemicになるのではない か, 免疫を持っている人が誰もいないので, 多くの人 が一斉に罹る可能性があるのではないかと危惧されま した。また相前後して，ベトナムにおいて院内感染と しての非定型性肺炎が同じく香港でも院内感染として の非定型性肺炎が報告され, この時点で, 新型インフ ルエンザの拡大がいよいよ始まったのではないかと言 う事で，インフルエンザを中心とした調査がスタート しました. しかし，中には通常のインフルエンザの感 染の方もいたようですが，そのほとんどは $\mathrm{H}_{5} \mathrm{~N}_{1}$ をは じめ既知の病原体では説明が出来ないと言う事が明ら かになってまいりました。

\section{(スライド 4)}

WHO は当初はアジアにおける不明肺炎の多発であ るとしましたが, シンガポール, さらにカナダ, ドイ ツと各地で不明肺炎の発症があり，しかもそれぞれ滞 在地として香港をキーワードとしているということか ら，WHO は世界中が共通して警戒すべきものとして Global Alert をかけました.

(スライド 5)

このような時に，どのような患者さんが，どこにど の位の数が発症しているのか, 或いはその患者さんは どういう風に移動してどのように他の人と接触したか などが分らないと新しい病気の追求が出来ません．し かし病原が特定できないという時点では, 確定診断を まって報告をする事は無理ですし，確定診断方法が あったとしても時間がかかります。そこで早くある症 状をもった患者の情報を集めるため,広く網をかける. つまり診断を行ってから報告を求める通常のサーベイ ランスではなくある症候群で見たグループの病気の サーベイランスが早く疫学情報を得るために必要とな るという考え方がありますが. 今回 WHO はSARS に関して症候群サーベイランスを世界的に始めまし 
た．我が国もこれに従って，スライドに示したような 症例定義でサーベイランスを開始しました。最近はこ れにコロナウイルスが分かってまいりましたので， SARS コロナウイルスの陽性例の場合には可能性例に 入れるという約束が出来てきております.

(スライド 6)

ただこの中には，除外規定があります．特に他の診 断によって病状の説明が出来たり, 明らかに細菌感染 症ではないことが分かってきたことから，細菌感染症 としてその経過, 臨床検查所見が十分説明できるもの については，除外をしょうという約束になっておりま す.

\section{(スライド 7)}

この患者さんの最初の発症の様子を見てみますと, 不明肺炎の院内感染のきっかけとなった疫学状況をみ てみますと, ベトナム・ハノイで入院し，八ノイの病 院で院内感染を生じさせた最初の例 (index case) は香 港から来た方で，ホテル Mに泊まっていました．また 香港で重症肺炎になって入院し，そこで院内感染を起 こした index case は，中国広東省から来た方で，やは りホテル M に泊まっていました. さらにカナダ, 米国, シンガポールなど他の国で発症した人もホテル M の 同一フロアーに同じ頃宿泊していたことがあるという ことが分ってきました，最初に発症した人はかなり感 染力の強かった人で, そこから中心にして輪が広がっ てきてしまったと, 疫学的に明らかになってきており ます.

\section{(スライド 8)}

もう一つ，当初病院内での感染という事で始まって いた SARS ですが, Amoy Gardens という香港のア パート群がありますが, 300 人以上の患者さんが出て 来たことがもう一つの問題点となって来ました.つま り, 院内感染に留まらず, 社会での流行のきざしが見 えてきたということをさす．しかし，どのアパートか らも一斉に多数発症したという事ではなく, 7 棟, 8 棟に患者さんが集中して発生しているという特徴があ ります. Amoy Gardens の周辺にはスーパーマーケッ 卜, 映画館, 人の集まる公園, 幼稚園, 学校があるの ですが，そこからも集団感染の広がりが無く，ある特 定の棟を中心にして広がっているということがござい ます。

(スライド 9)

その原因については, 他の先生から説明があると思 いますが，患者とのつながり，のみならず環境からの
感染からも若干の可能性があるとされています. 当初, 院内感染としての中心だったSARS は，発症者につい て疫学的な調査を追求していくContact Tracing を 行っていきますと, 社会へ拡大していく可能性も証明 され，この点について，新たな対策が必要となってき ております。

(スライド 10)

香港の Amoy Gardens における患者さんの年齢分 布ですが，もちろん住んでいる人の年齢に応じて発症 者が多くなるという現象があろうかと思いますが，30 代に多いという事，もう一つは小児に少ないという事 が, この病気の特徵的なところであります. 小児に少 ないということについては十分な説明がまだ出来てお りません．また，香港において入院した患者さんにつ いての致死率を見てみますと，これは年齢に応じて高 くなっています. 60 代, 70 代あたりでの致死率が非常 に高まっている中で, やはり 10 代，あるいは小児とい うところでの致死率は極めて少ない.小児にとっては, 羅りにくく悪くなりにくい，だからといって子供が安 全という訳では無いのですが，そういった現象もだん だん分かって来ております。

もう一つ, 社会への拡大というもので問題となりま すのは, 航空機内での感染です. 確かに一部の航空機 では乗り合わせた乗客の数名に感染が拡大しておりま すが, その航空機には目下 10 機以内に特定されており 患者さんが乗っていた飛行機が，すべて遍く皆に感染 を拡げたということではないようです，何機かの航空 機にたまたま乗り合わせた方が激しい感染を受けてい る.つまり皆等しく感染力を持っているのではなく, かなり感染力の強い人が抢られ，そこから感染が拡大 しているという特徵があるようです。これも Contact Tracing という疫学的手法によって分かってきまし た.

\section{(スライド 11)}

SARS の感染経路は主には院内感染を中心に拡がる ような飛沫感染, あるいは接触感染でありますが, な かには飛沫核感染，あるいは環境の感染を考えなけれ ば説明ができない部分もあります．ただしその時の感 染力には, どうも個人差, あるいは病気の stageによっ て差があるようで，概念的にそのような感染力の強い 方を Super Spreader と呼んでいます.ただしこれは結 核の患者さんで喀痰をとってみてガフキーの何号と いったような菌量（ウイルス量）区別ができるもので もありませんし, あるいは, その特定な方の免疫状況, 
あるいは体質，そういうものまでまだ言及されている ものではありません．しかし, Super Spreader と考え られるような感染力が強い方は, どうもその経過が重 い，なおかつ予後が不良であるというようなことがご ざいます，逆を言えば肺炎になった場合でも，それほ ど重症化していない方，軽症化ですんでいる経過のい い方は比較的感染力は少ないと言えるようでありま す.病気の stage で見るならば, その感染の状況は肺炎 の極期にもっとも感染力が強くまたその手前の発熱時 での感染はありますが極めて少ない，というのが現在 の状況です．無症状者からの感染の有無は問題になる ところですが，一部での例外的な報告を除いては無症 状者から感染発症したという報告はありません.WHO は 0 か極めて少ない，その可能性は極めて低いといっ たような表現をしております。

\section{(スライド 12)}

院内での感染予防については, 次の演者の先生から 詳しく説明があると思いますが，SARSにおいても標 準予防策の考え方の導入ということは極めて重要と なってきます。ことにスクリーニング，あるいはトリ アージの段階で必要です。さらに肺炎の患者さん，あ るいは患者さんであろう人を診る場合はバリアナーシ ングという考え方を導入していく必要があると思いま す.

\section{(スライド 13)}

治療については後の先生方にお願いして, 詳しい事 は省略致しますが，ウイルス性感染という事からいえ ば，適確な抗ウイルス剂の治療が現在，このコロナウ イルス感染症についてはございませんので, 対症療法 が中心になります，現在，幾つかの治療法が薦められ ておりますが，いずれも含意された標準的な治療法と いうものは現在ありません，病原微生物が見つかって おりますので，このワクチンについては期待ができる ところではありますが，理論上あるいは実験段階とし てでできるということと，実用化になるということに はかなり時間的に差がありますので，現在のところワ クチンについては無いという表現の方が正しいという 事になります。ただし勿論期待はできます。

\section{(スライド 14)}

一般的な消毒ですが，SARS コロナウイルスの消毒 はそれほど困難ではありません，envelope を持ったウ イルスに大体共通な事としてまず，熱に極めて弱い， $80^{\circ} \mathrm{C} 10$ 分で失活してしまいます.アイロン掛けも有効 です。または紫外線に弱いので日光に干すあるいは紫
外線照射をすることが，極めて有効であると考えられ ます.また，通常に用いられる $80 \%$ 消毒用エ夕ノール， あるいは速乾性の皮膚の消毒剂を適切に使用するので あれば，これらによる失活の可能性が十分に期待でき ます．ただし適切に使うという事が重要です，家庭用 では漂白珮などが簡便で効果があります。あるいは人 には使えませんが，器具類には過酢酸，グルタールア ルデハイド,が消毒戍として入手可能な物であります。 若干弱くなるようですが沃素系の消毒片も有効かと考 えられます。

\section{(スライド 15)}

病原診断については，田代部長が詳細を申し上げま すが，遺伝子診断，ウイルスの分離同定，血清診断は 我が国で可能となってきております。

（スライド 16）

ただ我々が今みている「SARS」「SARS ウイルス感 染症」というのは，極めて典型的な上辺だけをみてい るのかもしれません．その中にはあまり熱が出ない， あるいは咳だけで留まったのか，まったく無症状の方 もいるのかもしれませんが, この辺は血清疫学, ある いはウイルス病原的診断が進むに従ってわかる事で す。しかし，今この議論をしても全体像は掴めません． 従って今, 早く理解をする為の方法は, 典型的な部分 に集中をする必要があります，だんだん分かってくる と, 本当は典型例として出てくるのはほんの僅かで あって, 後で良く見れば抗体陽性例が無症状から出て いたとか，非典型例でしばらくたってみるとウイルス が証明されたが二次感染はなかったとか，そういった ことが分かってくると思います．病原が見つかってわ ずかしか経っていませんので，すべてをエビデンスを もって語るわけにはいきません，徐々に解明している 段階であります。

\section{(スライド 17)}

全体像を重要なところに限ってまとめてみました。 この病気の臨床経過と感染性が予防対策上重要な部分 になります．例外的なものを除けば，一応，潜伏期間 は 2 日から 1 週間,ちょっと長めにみても 10 日を過ぎ て発症する例は極めて稀であるということが, 10 日間 様子をみて何も無ければ普通にして下さいという根拠 になります.それから前駆症状が 1 日，2 日，長いと数 日位のことがありますが，これが発熱，咳などのイン フルエンザ症状になります。その他幾つかの随伴症状 がありますが，やがて肺炎としての本格的症状が出て きます。そしてその中の $90 \%$ は回復をしております。 
約 10\%が ARDS 症状をとり, 極めて重篤な経過をと り，死に至る人がこの中に多く含まれてくることにな ります。また，感染力についてみますと，肺炎時期が 極めて感染力が高い，これが特に病気の患者さんを診 る側にとっては十分注意が必要となるところです．前 駆症状期が，まだはっきり分らない，あるいは外来に いたり，入院をしょうかどうしょうかとの時期だと思 いますが，発熱時期での感染力はそれほど強いもので ありません．しかし，感染力はあるということが前提 であるように対処しなくてはいけないと思います。潜 伏期における感染性は現在の知見では無い。あるいは 感染性は極めて低いものであるということがまとめと して言えると思います。

(スライド 18)

幾つかのこれまでに得られた知見をまとめたもので ありますが, 感染のルートとしては, 濃厚な接触, あ るいは飛沫感染が主な感染経路であります.なおかつ, 濃厚接触であればあるほど, その感染発症の可能性が 上がるわけですが，こういったところがバリアナーシ ングが必要になるところです．それから症状の無い人 であるならば, 感染の可能性はゼロまたは極めて低い。 このような中で（肺炎の人がふらふらと外を歩いてい ないということが前提ですが）街中ですれ違っただけ だとか，たまたま電車に乗り合わせて離れているとこ ろに座った，というょうな感染の可能性は極めて低い と考えられます，もちろんゼロであるとは，なかなか 言い切れないですが, この可能性は極めて低い. 先ほ ど公共機関を使っての患者さんの運び方, 或いは ちょっと心配なだけの方をどのように帰すか, といっ たものはこれらの応用問題となって考えることになる と思います. それから環境の器物を介した感染の可能 性があると書いてありますが，これは感染力のある人 が触れたものについては, 他の病気と同様であります が, 感染性の可能性があるものとして処理をする必要 があるという意味になります。今までの知見では食物 感染, いわゆる food-bornのものではない. それから輸 入品で何か起きたという事例もありません，炭疽事件 以来, どうも郵便物がものすごく注意を受けておりま すが, 現在, 感染発症地域から来た郵便物で誰かが遠 いところで発症したような報告はありません，WHO はこういったものに制限をかける必要はないといって おります. 主な感染は接触感染, 飛沫感染ですが, ア モイガーデンあるいはホテル M あるいは航空機内, と いうことを考えるならば現在の段階でエビデンスを
もって飛沫核感染，空気感染の可能性を否定するわけ にはいかないので, これは感染力が強いと思われる患 者さんを扱われるところでは, 空気感染を含めた取扱 が必要であることになります.

(スライド 19)

先ほどの加地室長から外国から来た旅行者の件をご 紹介いただきましたが，状況をまとめたものがこれで す.今回は海外からの旅行者発症例ですが,これをもっ て感染の可能性があるのに入国してくるのはもっての 他などということを声高に言う方もおられます。たま たまSARS でありますが，我が国から海外へ出してい る例もあります，麻疹などは真面目に対策をしていか ないと, 同じょうなことが海外から言われた時, どの ように説明ができるでしょう。感染症とはそういうも のに対して，広く注意をしなくてはいけないというこ とです．今回の事例は発生した国から日本に団体旅行 で来た方が，国内に入る時は特に症状がなかったです けれども，国内で発症したということであります．つ まり日本に入って来た時は感染力は恐らく無いし, ご 本人もまったくその気ではなかったと思います。帰国 後入院されましたがその予後は良好であると聞いてお ります. Hyper Spreader という概念でいうならば, か なりその Hyper Spreader であれば予後が悪い, 死に 至ることもあることから，この方は Hyper Spreader ではなく, 結果的に我々には極めてラッキーだった, ということであります。またもし感染をするのであれ ば，近い距離であればあるほど感染をするチャンスが 多いので，実際にはツアーに同行された方，あるいは 同じ航空機内での発症者がないということから，この 点もかなり感染力が弱かったということが言えます。 ただし，国内において濃厚に接触した人は，その時の 段階においては不明だったものですから, その方の健 康状況をチェックせざるおえない, Contact Tracing をやらないとこの SARS の後の広がりが分らないと いうことで, 色々な議論がある中で, 旅行者の行程等 が公表された訳です．ある地域に行ったということが 一般の人々に分かっただけでは，そこの人たち全部が 心配になってしまいます。 ある程度絞り込んで, 何月 何日の何時頃という情報があれば，かなりの対象を絞 り込み事が出来るので, 調べることもできるし, 多く の人が安心することもできるという一面があります. 勿論すべての人の調査をできる訳ではありませんが, そういったことをやった結果, この方から二次感染を するのであれば,この方が去ってから 10 日間以内に発

平成15年 8 月 20 日 
症者が出てくるだろうと考えられるわけですが，幸い に発症者と思われる方は国内の Contact Tracing の中 では出ませんでした。しかし，これはむしろ社会的な 問題があったのですが，それでもなおさらに消毒をす るとか, 出入りも危ないのではないかとの話も出てく るのですが，これは全く意味がありません．むしろや る必要は無いということも強調する必要があるのでは ないかと思います．ただし，本当にその後の拡大が無 いかということを確認するためには，ある不明であっ た人からさらにそこから広めた可能性もあるので，通 常, 潜伏期間の 2 倍は調査期間として重要な期間と設 定しておく必要があります。したがって，この方が国 内を去ってから 20 日間は, やはりそう言う意味での注 意をしていく必要があると思われます。

(スライド 20)

感染症情報センターではホームページを開設してお ります.その中に今回緊急情報「SARS」というボタン を付けまして，このSARS については，なるべく早く より正しい情報を扮伝えしょうと思って揭載・更新し ております．例えば，世界中でどの位の患者さんがあ るか，あるいは我が国での報告数は現在何件か. WHO が毎日のようにその方針を新たに発表してくるのは大 変ではありますが，それだけ知見が確かなものに置き 換わってくるので，それを分かり易くするため日本語 版として連日，翻訳をしてだしております。また国が あるガイドラインを出すというのは極めて時間的に難 しい場合があるので，その手前の段階として，スタッ フの中でディスカッションをして常識的にこの辺なら ば許容してもらえるのではということで, 情報セン 夕ー案として対応策のようなものを提示しておりま す. 絶対従うものではなくこれを基にして一番御自分 のところで行ないやすい吒き台として考えていただけ ればというものです.ですのでこれを金科玉条にこの 方法ということではありませんし，色々な知見が集 まってくれば変更の可能性も出てきますが，いずれに してもある程度応用問題をやらなくてはいけない時 に，一つの考え方をはじめるきっかけになっていただ ければと思っております。

（スライド 21）一般医療機関の先生方には，これも 我々の提案ですが，本来は普段からもっと感染症の対
策というものを持っていただきたいと思います，日頃 から例えば空気感染と考えれる麻疹がきたらどうしょ うかとか，実際にはSARSを診るより結核を診る方が はるかに可能性として多いですが，その結核患者がき たらどうしょうかという備えがあれば，これはかなり 応用問題ができると思います．実際に麻疹は医療機関 での感染発症が多く，そこから死亡者も出ています. 結核の患者さんをどうしょうかということなしに SARS だけの対策をとっても十分なことが出来ないだ ろうと思っております。

(スライド 22)

しかし，すべての医療機関が今すぐ隅々まで考え方 と準備が行き渡ることは無理であります。しかし現段 階で少なくとも初期対応の整っている医療機関ですと 最初のトリアージが可能であります。もしそういった 対応策が整っていない医療機関ですと初期対応した場 合，感染者が来れば拡大の可能性があります。この場 合は適切な医療機関を紹介していただければ，きちん とした患者さんに対する説明になるのではと思いま す。これもなしに当医療機関では診ないというような ことでは，相談もしないのかと患者さん側からの問題 点の提議が十分あるのではと思われます。そういった 適切な医療機関は，入院ではなく外来における follow up はどこが可能なのか, 是非地域で話し合いをしてい ただきたいと考えております。

(スライド 23)

今日は専門家の方々ばかりですが，一般の方々への お願いです．診察室で診てみたら既に熱があって昨日 海外から帰って来たということがわかるのは，まった く遅いわけですでに待合室と䛦療室で拡げてしまって いる可能性もあります。そういう方は予め電話で相談 をいただいて，どこに行ったら良いのかまず相談をい ただくのがいいのではと思います．是非，そういった 事を多くの方々にアピールしていく必要があると思い ます.そしてその相談受け入れ先が，医療機関であり， 保健所であろうと思います。早期発見というだけでは なく, 家族, 周囲の人, そして一番問題となる院内で の感染の拡大予防に役に立つであろうということで, 一般の方々への協力を求めることも必要となろうかと 思います。 
スライド 1

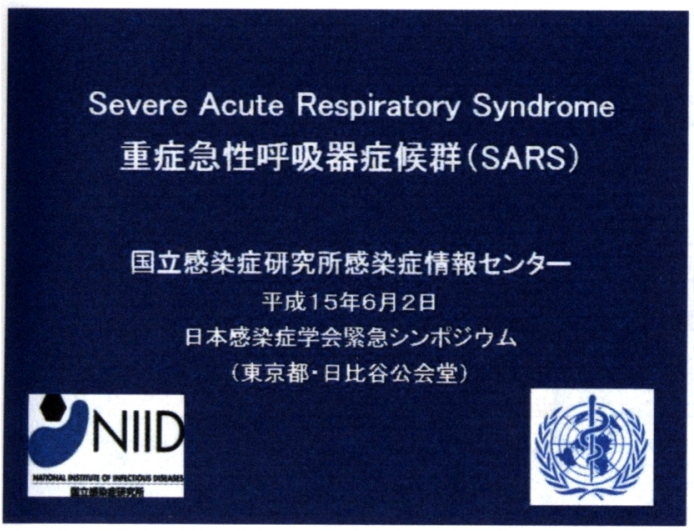

スライド 2

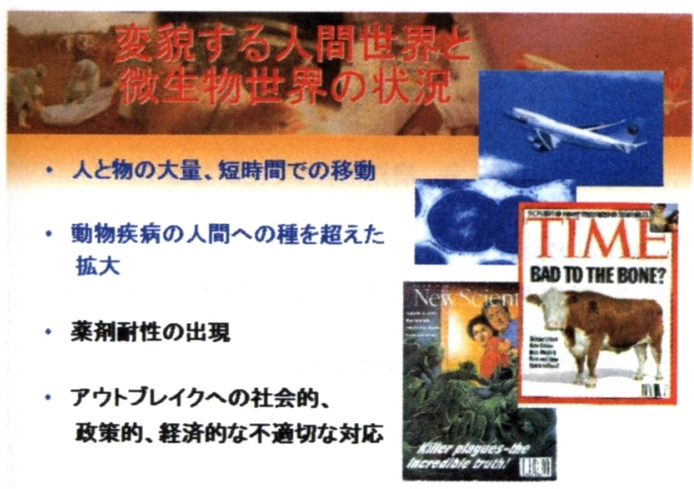

スライド 3

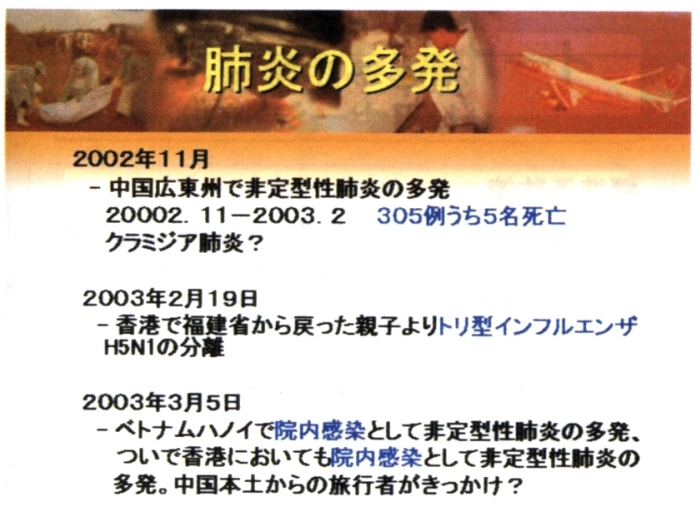

スライド 4

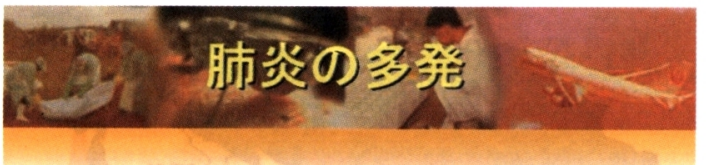

WHO:アジアにおける不明肺资の多発

$$
\begin{aligned}
& \text { 2003年3月14日 } \\
& \text { シンガポール } \\
& \text { 2003年3月15日 } \\
& \text { カナダ } \\
& \text { ドイツ } \\
& \text { での患者発見 }
\end{aligned}
$$

$\rightarrow$ WHO: Global Alert

スライド 5

原因不明重症急性呼吸器症候群(SARS)

報告基隻

-症候群サーベイランス-

対象:全国医意機関

铰い例: 2003年2月1日以降で

38度以上の急な発㷫

鲩、呼吸困建などの呼㖟器应状

から

発生地域人旅行

SARS患者への密な椄触があつた

可能性唰: 锗い侧プラス

㽛部レントゲンで盹炎。

またはARDSの剖険所見

㽎い+SASR COV 昌性

\section{スライド 6}

原因不明重症急性呼吸器症候群(SARS) 報告基隼

-症候群サーベイランス-

除外規定 (削除ではない)

1. 他の診断によって病状が説明できるもの

2. 標準の抗生剂治療等で、

3日以内に㱏状の改善を見るもの

(細菌性感染等抗生剂反応性疾患の可能性 が高い) 
スライド 7

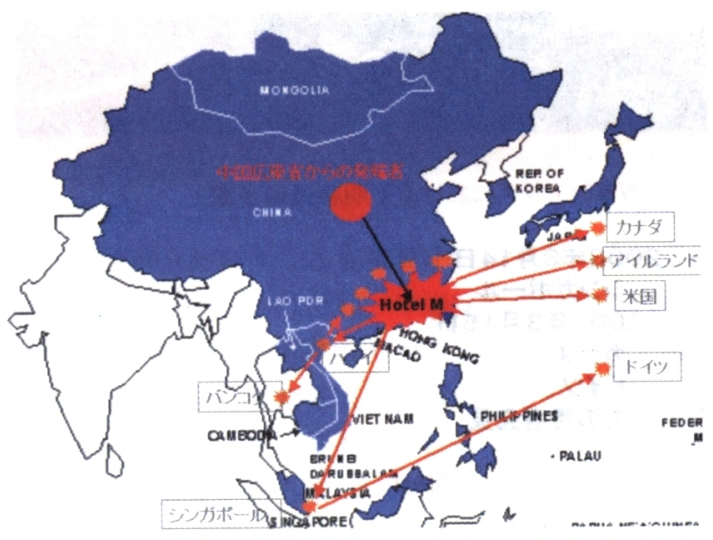

スライド 8

New housing complex cluster in Hong Kong

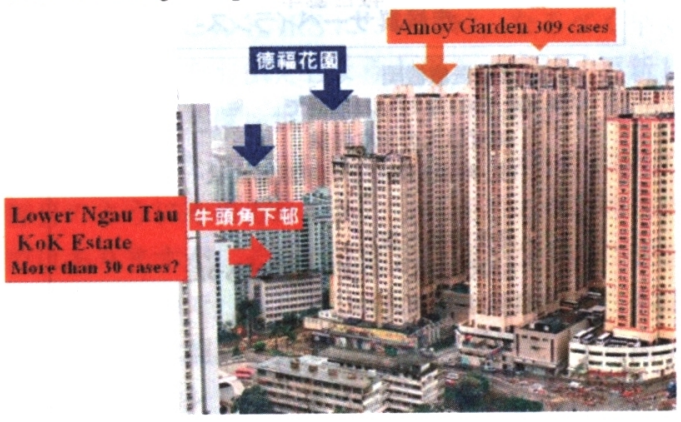

スライド 9

\section{当初、院内感染としての問題}

$\downarrow$

発症者の疫学調査

Contact Tracing

社会への拡大
スライド 10

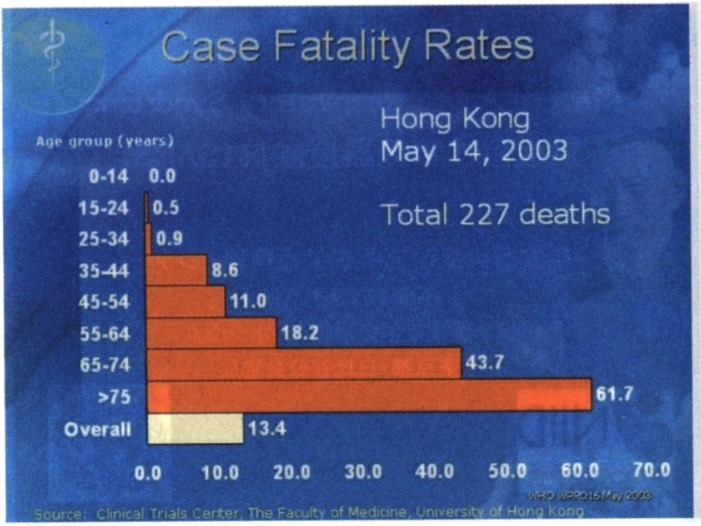

スライド 11

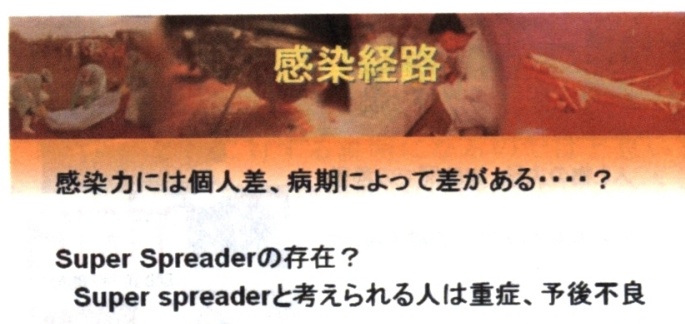

肺炎の極期に感染力は最も高い

発熱時の感染あり

無症状者から感染を受け発症したとの報告はない

スライド 12

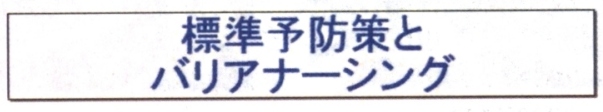

- 標準予防策

一患者の血液·体液や患者から分泌排泄され るすへての湿性物質 (尿·痰·便·膿) は感染 のおそれがある（除く、汗·淚）

・ バリアナーシング

一呼吸器、粘膜からの感染を防ぐ厳密な感染 防御対策 


\section{治療}

- 対症療法

・リパビリン(静注) \&ステロイド

・インターフェロン

- 抗HIV治療薬

- 血清療法

・ワクチン 未

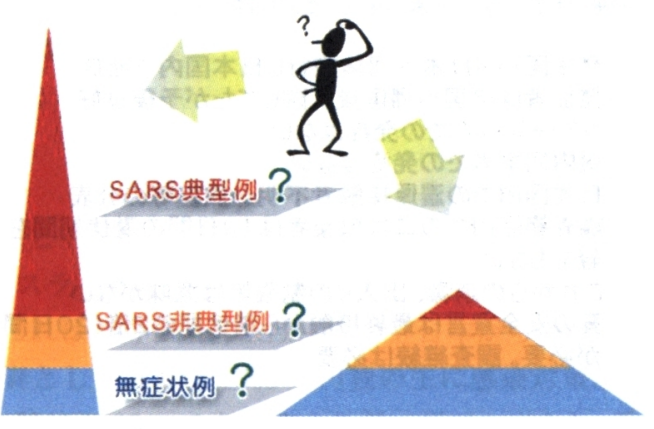

スライド 17

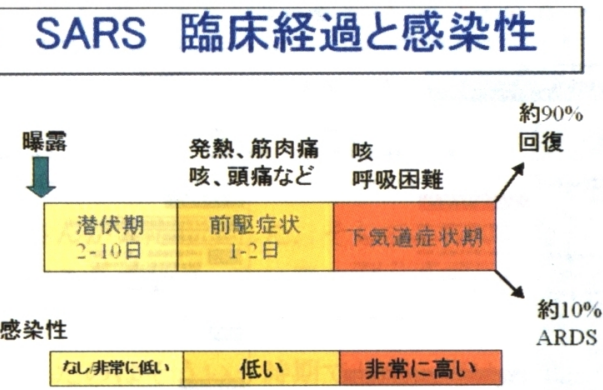

スライド 18

\section{基本となる知見}

- 濃厚な接触と飛沫感染が主な感染経路

- 濃厚接触をすれば感染発症の可能性は上がる

- 市中での感染の可能性は低いがゼロではない

- 症状のないヒトからの感染の可能性はゼロまたは 極めて少ない

- 環境からの器物を介した感染の可能性がある

- 食物·輸入品·郵便物からの感染発症報告はない

- 空気 (飛沫核) 感染の可能性は否定できない 


$$
\text { スライド } 19
$$

\section{海外からの旅行者発症例}

発生国から日本へ団体旅行し日本国内で発症 発症者は自国へ帰国後入院してたが予後良好 ツアー同行者での発症はない 機内同乗者での発症はない

日本国内での濃厚接触者不明 $\rightarrow$ 旅程等の公表 調査範囲内での二次感染者は10日間の潜伏期間を 経てもない

これからの消毒、出入りの制限等は意味がない 真の安全宣言は最終接触から潜伏期の2倍 (20日間) が必要。調査継続は必要

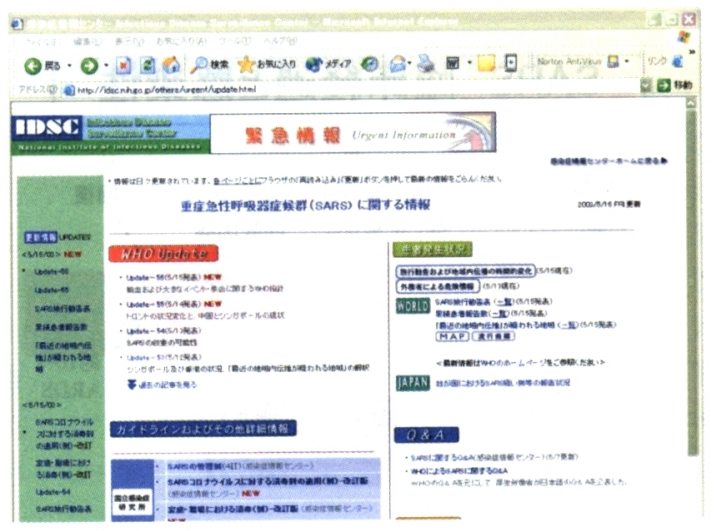

スライド 21

\section{一般医療機闠の先生方へ -提案-}

\section{日頃より感染症患者の感染予防への注意を}

・摽準予防策の考え方

・麻抮患者が来たら、結核患者が来たら・..

手洗い、N95マスク・外科用マスクの備え -問診: 発熱の有無、渡航歴は受付の段階で チェック
スライド 22

\section{一般医療機関の先生方へ}

·感染症初期対策の整っている医療機関では、 初期対応が可

·感染症初期対応策が整っていない医療機関では 初期対応はしない方がよい

＼cjkstart適切な医療機関の紹介を行う

·適切な医療機関の登録、把握(保健所·医師会。2
スライド 23

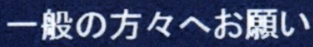

海外など発生地域から师国した方

SARS(と思われる人)と近距離での接蚛があつた方で

急激な発熱、咳、呼吸困雄があった場合

受付、診察室でそのことを話すのではなく、

電話などであらかしめ医療機関、保揵所などで、と゚この医癔機関 へ行くベきか、ご相談下さい。

もしSARSであった場合、早期発見、家族、周囲の人、院内での感 染掋大予游にもっとも役立ちます。

こ㙝力下さい 


\section{SARS 制圧実例}

国立国際医療センター呼吸器科

川名明彦

\section{(スライド 1)}

国立国際医療センター呼吸器科の川名と申します.

現在, SARS の症例は世界中で増加傾向にあります. しかし，その流行の比較的早い時期に outbreakに見 舞われたものの, 感染対策が上手く行き, コントロー ルができた国が幾つか出ています。べトナムはその中 のひとつです. 私どもはべトナムの流行の時期に現地 の様子を見ることができましたのでその経過について 御報告したいと思います。

\section{(スライド 2)}

先ほどもお話がありましたが, 今年の 2 月頃, ベト ナム, 香港, 中国の広東省におきまして重篤な原因不 明の非定型肺炎の流行が始まりました。これを受けて， 3 月 12 日に WHO が非定型肺炎に関する緊急警報を 発しました. WHO が創立したのが 1948 年ですが，そ れから現在に至るまでこの様な Alert が出たのは初め ての事だそうです。その中で特に医療スタッフに多数 感染者が出ていることについて強調されました。これ を受けてべトナム政府は日本政府に緊急の援助を要請 しました.このため 3 月 16 日, 日本政府は JICA を通 じて感染対策用機材の供与と国際緊急援助隊専門家 チームの派遣をしたわけであります．私と次の演者の 照屋先生と JICA の専門家の 3 人で 3 月 16 日にハノ イへ行きました.

(スライド 3 )

少し時間が前後しますが，5月 27 日に至るまでの SARS の累積症例数であります. 赤が香港, 青の中国 は, 依然として増加傾向にあります. 香港は最近安定 してきております。紺色の部分が台湾ですが, 依然と して増加傾向にあります．黄色がベトナムです．私ど もが行きました 3 月 16 日は,一番左の部分に相当しま すが,ここの部分を拡大するとこのようになります.

(スライド 4$)$

この段階で WHO の報告によりますと，世界で未だ 100 例にも充たなかったのですが，その過半数をべト ナムが占めていたという状況です，実はこの段階で, 中国でかなりの流行が始まっていたのですが，公式な
報告としては，このような形となっていました.

(スライド 5)

これは 3 月 16 日, 出発日です. 日本からの緊急援助 物資として合計で 1300 万円程の主に感染対策用の器 材, 特に N-95 マスクやディスポーザブルガウン, 手袋, 2 台の人工呼吸器といったような物を持って行きまし た. 私どもが着きました時には, ベトナムでは八ノイ の 2 つ病院にSARS の患者さんが収容されており ました。

(スライド 6)

一つはフレンチ病院, もう一つがバックマイ病院で あります.これはほとんど隣り合わせの病院です.フ レンチ病院に香港から来た最初の SARS 症例一最初 はSARS との認識は無かったわけですけれど一最初 の患者さんが入院しました. そしてここで爆発的院内 感染が起こりまして, 次に隣のバックマイ病院に患者 さんを収容するという形になっていました，丁度，私 達が行ったのはそういう時期でした．実はバックマイ 病院は, 以前から日本とは非常に馴染みの深い病院で, この建物は 2000 年に日本の無償資金援助によって建 てられたものです。この後も日本から交代で専門家が 現地に行っていまして, 特に院内感染対策についても, 以前からかなり意識の高い病院であったということが 想像できると思います. 先ほどのフレンチ病院とバッ クマイ病院ですが，ここでの流行の概略をご説明致し ます.

\section{(スライド 7)}

はじめに香港から 2 月 26 日に発熱した患者さんが 来ました. そしてハノイのフレンチ病院へ肺炎として 入院されています.この段階では, SARS という疾患概 念がありませんでしたので, 通常の肺炎として対応さ れていたと思われます.そうしましたところ, 1 週間ほ どして, フレンチ病院の中で医療従事者にぞくぞくと 院内感染が発生したわけであります. 最終的には, フ レンチ病院は診療機能を停止することになりました. この段階におきましてWHOが，院内感染をおこしや すい新型の肺炎であるということで, 3 月 12 日緊急警 
報を発しました.この過程において, WHO の専門家で あります Carlo Urbani という医師が感染してお亡く なりになっております. 次はバックマイ病院が患者さ んを受け入れることになったわけですが, この段階で はもう既に緊急警報が出ていましたので，一般病棟に 患者さんを受け入れるということはしませんでした. 具体的には病院の敷地内にある, 別の建物である熱帯 病研究所附属病棟に患者さんを隔離するという政策を 取ったわけです。

(スライド 8)

そういうところに私達が行くことができまして, バックマイ病院で意見交換や情報収集をしたわけであ ります。

\section{(スライド 9)}

これは最初の患者さんを受け入れたフレンチ病院で すが,こちらでは爆発的院内感染が起こってしまいま した. 私達が行った時に入院していた患者さんは 39 人ですが, その中で実に 36 名が医療スタッフだったわ けであります，その内訳を調べたものですが, ピンク 色が看護師, 黄色が看護助師, 看護スタッフ併せて半 分を占めている. そしてこれが医師であります。その 他, 患者さんの家族が 3 名ほど, その他, 洗濯の職員, 欴房の職員などにも感染者が出ていました。

(スライド 10)

これはSARS の 1 例で, 27 歳の女性です. 非常に重 症な肺炎であるのがおわかりいただけると思います.

(スライド 11)

日本から感染対策用の器材を持って行きましたの で, バックマイ病院, ハノイ, 現地の $\mathrm{WHO}$ 事務所な どに供与致しました。

\section{（スライド 12）}

バックマイ病院では WHO の警報を受けまして, 或 いは日本の物資供与を受けまして, 患者さんの受入当 初から徹底した院内感染対策を開始しました。具体的 には，まず最初に敷地内の別の病棟に患者さんを隔離 しております。これが先ほどお示ししましたバックマ イ病院のメインの病院の後ろにあります, 熱帯病研究 所の病棟です.この 2 階, 3 階に SARS の患者さんを隔 離するということをしています。棟等から供与を受 けました N-95マスク,フェイスシールド, ディスポー ザブルガウン, 手袋といったような物を使ってこのよ うな感染対策を始めています. その他, ご家族の面会 の制限ですとか，あるいは職員であっても不必要な出 入りはしないといったような対策を行なっています.
あと部屋の状況ですが，もちろん院圧室は無いわけで すが,このように空が大きく開いていて，換気をされ ていたと考えられます.

\section{(スライド 13)}

これはバックマイ病院とフレンチ病院を両方併せ て，日ごとの患者さんの発生数を示した図です．赤が 医療スタッフです. 2 月 26 日に香港から最初の index case が入院してこられまして，それから丁度 1 週間の 潜伏期間を過ぎた頃から医療従事者の感染が多発して おります.WHO の緊急警報が出まして, そしてバック マイ病院に患者さんの移送が始まったのが 3 月 12 日 です。この頃から，厳重な院内感染対策が始まりまし た.この後, 2 日後くらいをピークにして院内感染症例 はぱったりと終息しているわけであります。この後は 院内感染事例は 1 例も発生しておりません.また,バッ クマイ病院では職員への感染事例は 1 例も発生してお りません.

(スライド 14)

その後の経過ですが，赤が中国であります．これは 3 月 15 日から最近に至るまでですが, 未だに増加傾向 にあります．それから緑が香港であります．この香港 は比較的コントロールが良い状況になりつつありま す. 当初, 爆発的な outbreak を起こしましたベトナム は, その後患者さんの発生がないまま現在に至ってお ります。

\section{(スライド 15)}

この状況を受けまして4月28日にWHO はベトナ ムを SARSを制圧した最初の国として， affected area から除外しました。

\section{（スライド 16）}

このことにつきましては, ベトナムが SARS 制圧を 宣言したということで日本の新聞でも取り上げられま した．それに対して一方中国では対応が迷走したとい うことが報道されていました。

(スライド 17)

後日 (4月 8 日), ベトナムのファン・ヴァン・カイ 首相が日本に来られたときに, 宿泊先に呼ばれまして 協力について感謝の言葉をいただいたということがあ りました。これは一緒に行きました次の演者の照屋先 生,バックマイ病院プロジェクトという, 以前からバッ クマイ病院に協力をしておりました小原先生でありま す.

\section{(スライド 18)}

今回ベトナムはSARS の制圧に成功したといわれ 
ていますが，その一方では上手く行かなかった状況も

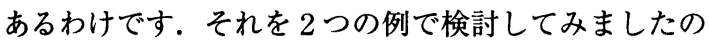
でお示し致します。

（スライド 19）

まず最初は, フレンチ病院, これは爆発的院内感染 が起こってしまった病院です.一方, こちらが1例の 院内感染も起こらなかったバックマイ病院です．その 二つにどういった差があったのかということを検討し てみました. フレンチ病院は最初にSARS という疾患 が認識される以前に患者さんを受け入れていますの で, 未知の感染症に対する準備が無かったということ があげられます，従いまして，当初は特別な感染対策 を実施していなかったと思われます。また，感染対策 用の器材は不足していたと考えられます。 それに対し て, バックマイ病院はWHOの Alert が出たその日か ら患者さんの受け入れを開始していますので, 最初か ら未知の感染症としての対策が出来た. 従って, 最初 から敷地内の別棟の病棟に患者さんを隔離することが 出来た. また, 患者さん受入時期が WHO や日本の援 助開始時期と一致した。従いまして最初から N-95 マス ク, ガウン, ゴーグル, 手袋などを使用することが出 来た. それから元々感染管理の意識の高い病院であっ たということがあげられると思います，もし，この段 階で日本に患者さんが入ってきたとしたら，恐らく日 本でもフレンチ病院と同じことが起こっていた可能性 があると考えられます。もう一つ, 成功例と上手く行 かなかったグループの比較ですが, 一方はその後, 患 者さんが増えてしまった中国, 香港を比較してみます.

(スライド 20)

中国, 香港は元々 SARS ウイルスの発生地と考えら れていまして, かなり以前から流行が始まっていた可 能性があります。また, 新しい感染症と認識された時 には, 既に市中に蔓延しつつあった可能性があります. また，特に中国におきましては，情報の公開が遅れて 国際的調查や援助を受け入れるのが遅れたということ が後で指摘されております。一方べトナムは最初は index case が特定できるような，たった一人の患者さん から始まったというような幸運があります，そしてこ の患者さんが市中に蔓延する前に病院内に囲い込まれ てしまったということがあげられます，また，情報公
開をしてWHO や日本などの援助を積極的に受け入れ たということがあげられると思います.

(スライド 21)

以上からべトナムに学ぶことは沢山あると思います が，二つご紹介したいと思います.

(スライド 22)

一つは感染防止の為の装備ですが，ベトナムのバッ クマイ病院では，このようなスタイルで感染を制圧し たというエビデンスがありますので, 私達の病院でも このスタイルを導入しております.

(スライド 23)

それからこれは病室ですが, ベトナムと日本を比較 しますと, ハード面, ソフト面でのリソースにおいて, 日本の方が遥かに優位であると考えられがちですが, 私は必ずしもそうではないと考えております.例えば, 国立国際医療センターにSARS の患者さんが来られ た時に入院していただくことになっている新感染症病 棟ですが，ハイテクによって管理されている陰圧室で あります．密閉された部屋であります．密閉された部 屋というのは，もともと医療従事者にとっては感染の リスクが高いところであるわけですが，それがハイテ クによってカバーされているということができます.

一方, ベトナムのバックマイ病院では陰圧室はないの で，空を大きく開けて換気をし，常に新鮮な空気を取 り入れているわけです．日本の東京のような都市型の 病院で, このような大きく空を開けてというようなこ とは中々困難な面もありますが，例えば空を大きく開 けて，新鮮な空気を取り入れながら診療をするという ことは, 患者さんや医療従事者にとって快適であるば かりでなく，感染対策面でも有利な部分があるかもし れない，といったところは今後さらに科学的な研究が 必要ではないかと考えております.

(スライド 24)

以上，ご紹介致しました．幸いなことに日本には SARS の患者さんは入っていないわけですが，海外で はどんどん知見が蓄積されていますので，そういった ことを活かして吸収し，もし患者さんが入って来た場 合には，医療従事者の安全を保ちつつ最良の医療を提 供できるような準備が必要ではないかと考えておりま す．御静聴ありがとうございました，以上です. 


\section{3月15日の世界のSARS累積症例数}

\section{SARS 制圧実例}

ーヘトナムに㧍ける流行之詨策-

国立国際医療センター叫吸器科 川名明彦
スライド 5

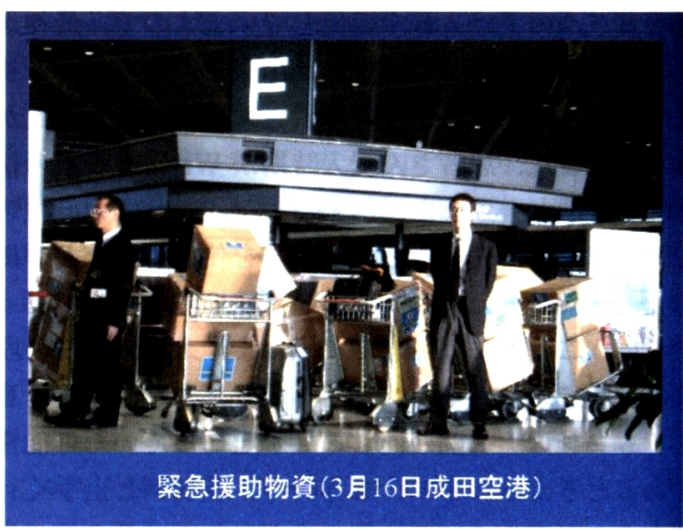

スライド 6

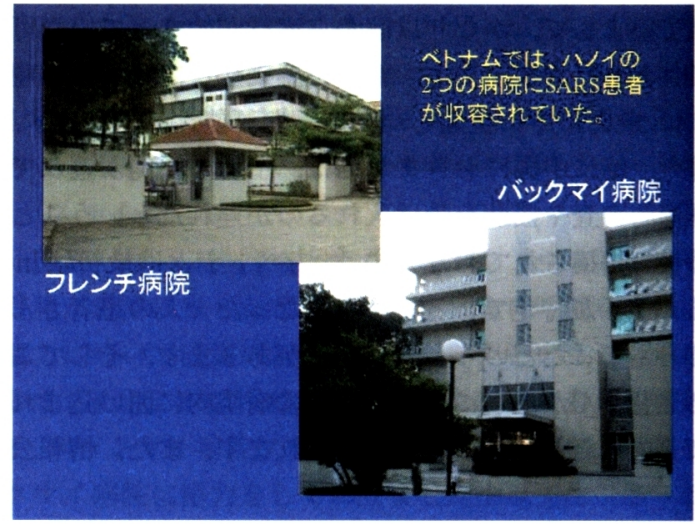

\section{世界のSARS累積症例数}

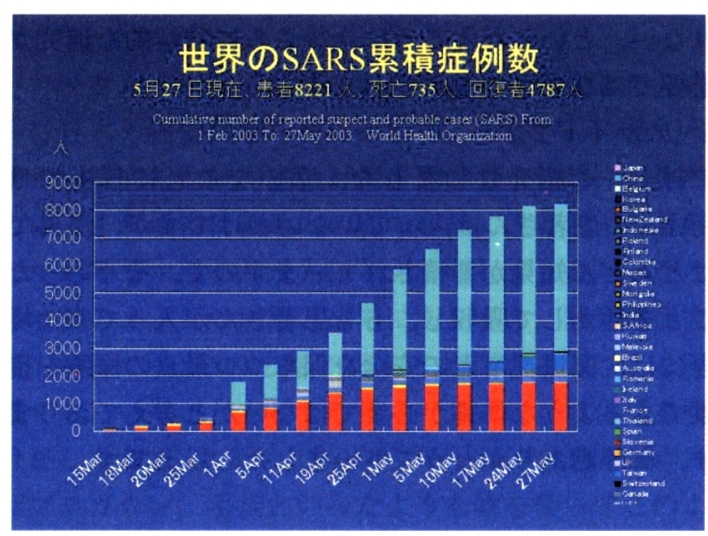

スライド 3
台浩

ats

シンガポール

ロペトナム
2003年2月、ヘトナム、香港、中国の広東省て重䔍な非 定型肺资の流行はじまる(特に院内感染)

3月12日,WHO が非定型肺燚门開する緊急警報 “特に医療スタッフにー多数感染者が出ている”

ベトナム政府は日本政府に緊急援助圭要請

3月16日、日本政府はJICAを通じ、感染刘策用器材の供与と 国際緊急援助隊専門家チームを派息した 
スライド 7

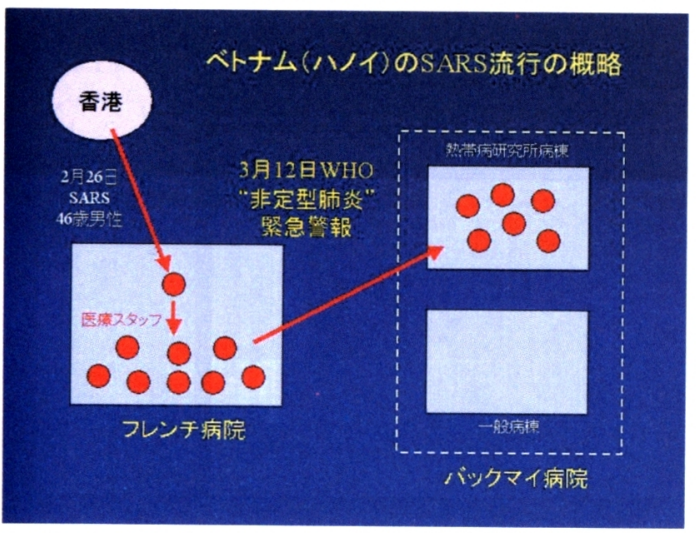

\section{スライド 8}

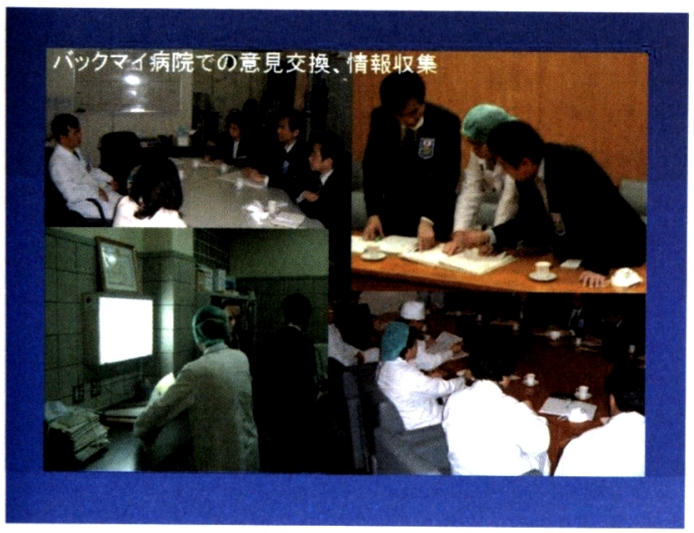

スライド 9

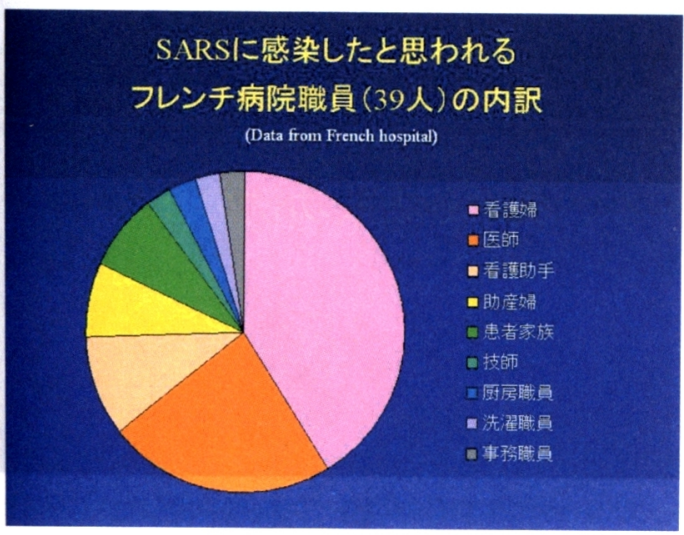

スライド 10

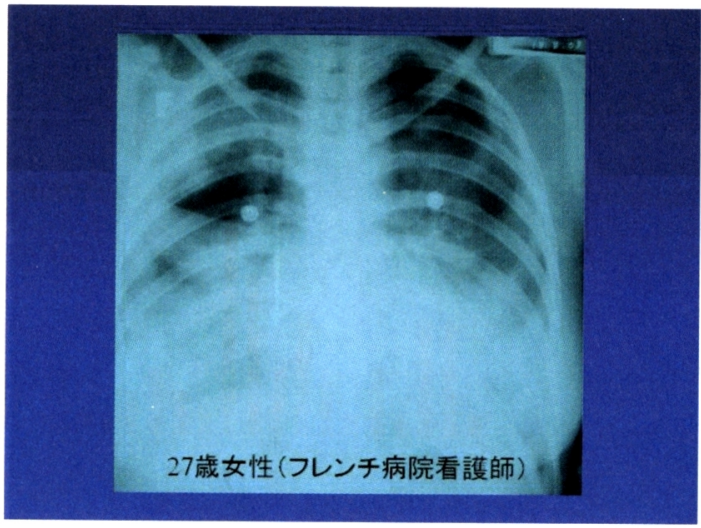

スライド 11

婜急援助物資 (感染対策用器材) の供与

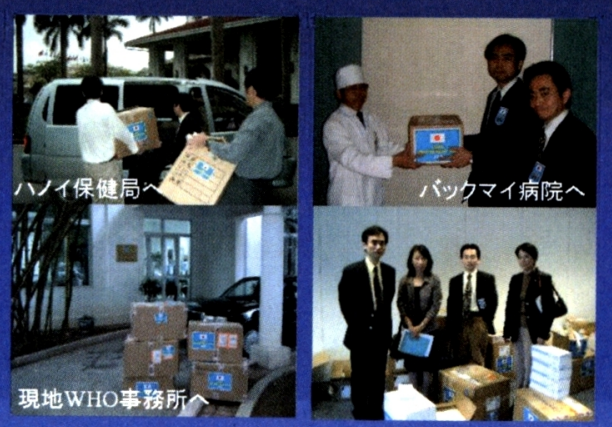

\section{スライド 12}

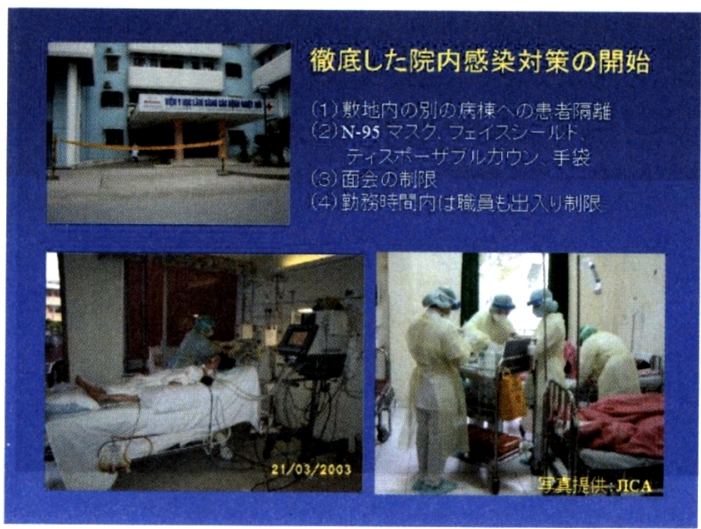




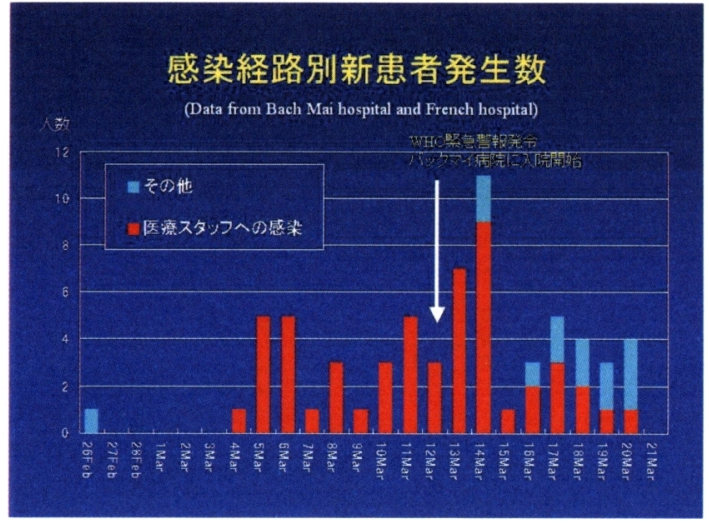

スライド 14

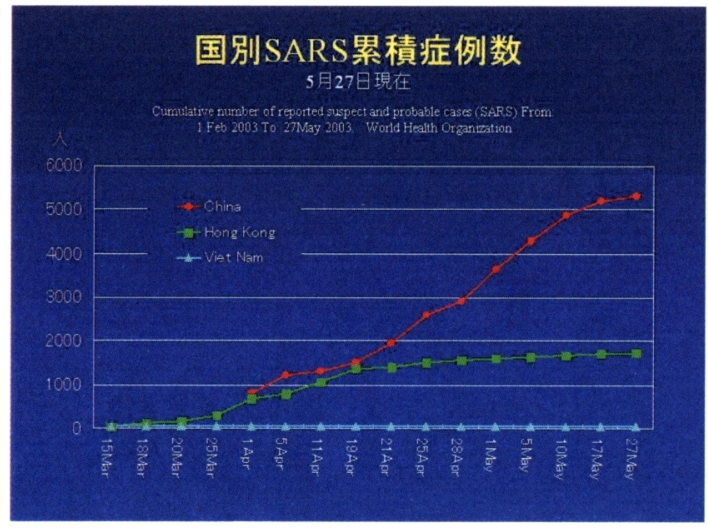

スライド 15

2003年4月28日WHOは、ベトナムか

“SARSを制圧した最初の国”としてaffected areaから除外した

Viet Nam removed from list of affected countries /WHO

28 April 2003
Viet Nam contains SARS

Viet Nam contains SARS

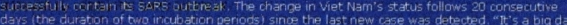

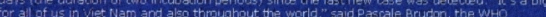
representatic in $\mathrm{t}$

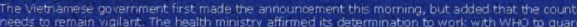
Ther

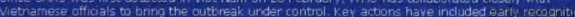

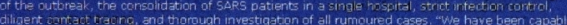

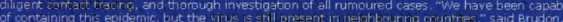

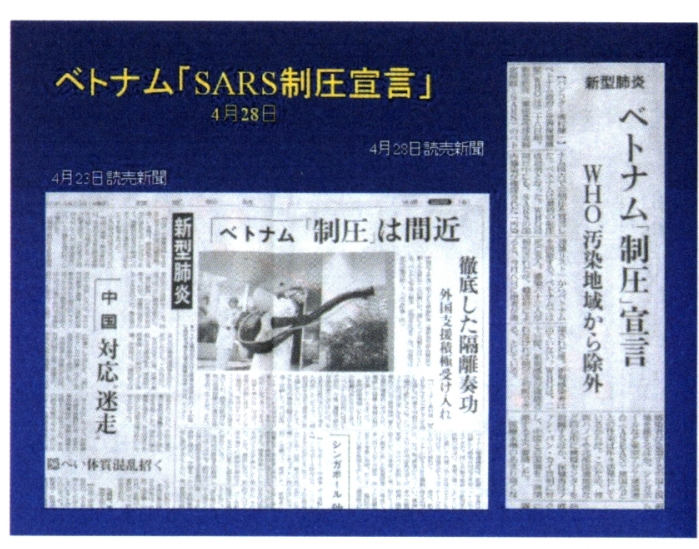

スライド 17

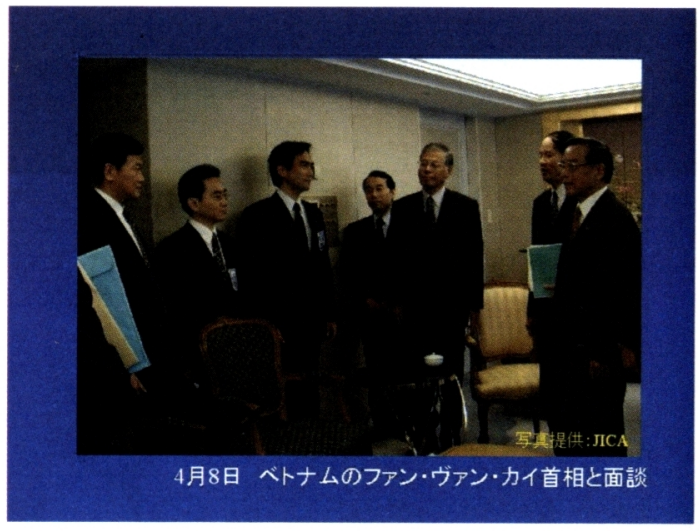

スライド 18

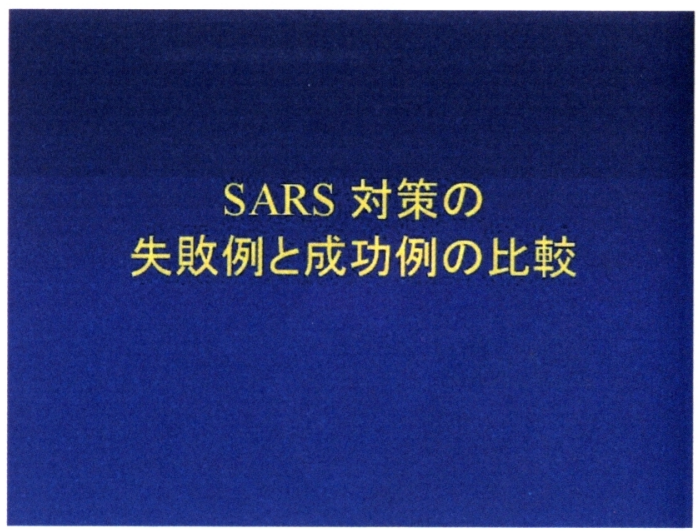


スライド 19

\section{フレンチ病院とバックマイ病院に生じた差異}

$$
\text { フレンチ病院 パックマイ病院 }
$$

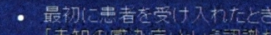

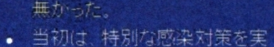

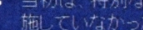

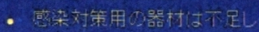

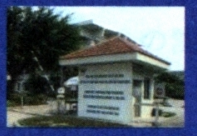

スライド 22

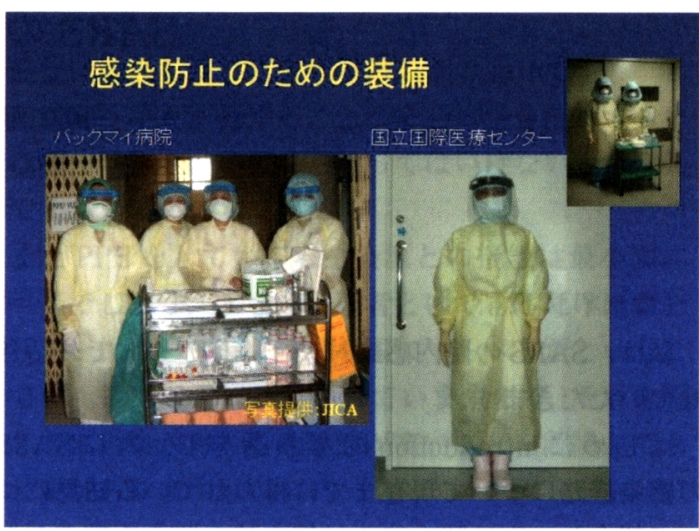

スライド 23

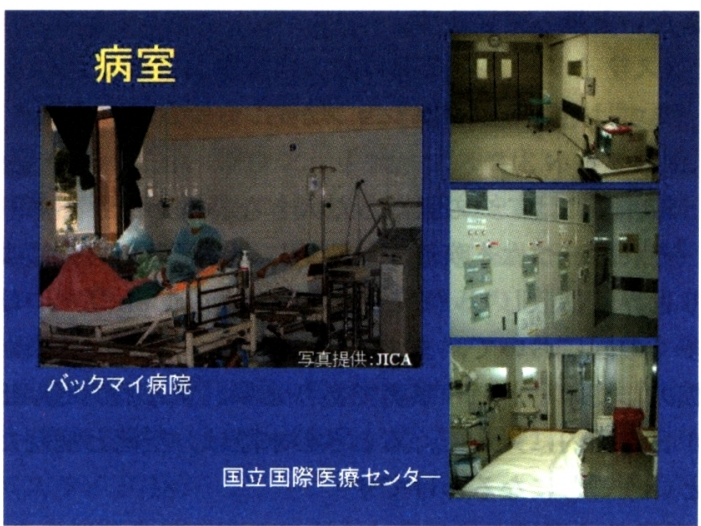

スライド 24

これまでSARS と戦ってきた他の国の多くの知見を いかし、「安全」かつ「最良」の医療を提供できるよう 準備し、努力する必要がある。

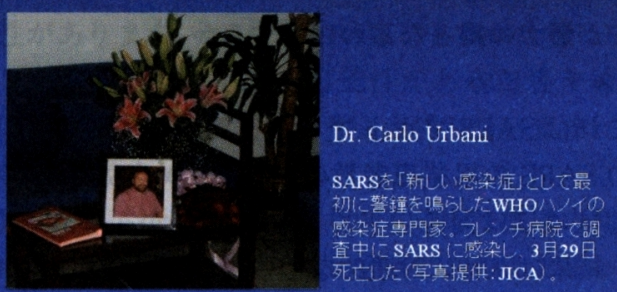




\section{SARS の院内感染対策}

国立国際医療センター

照 屋 勝 治

\section{(スライド 1$)$}

私は, SARS の院内感染対策というテーマでお話さ せていただきます.

はじめに introduction的なお話をし，次にSARS の感染経路について現在までに得られている知見につ いて紹介し，次に院内感染対策の基本概念を確認した うえで, 最後に院内感染対策の実際として国立国際医 療センターの取り組みを紹介する，こういう流れで行 きたいと思っています.

(スライド 2)

まずはイントロダクションから.

(スライド 3 )

SARS には二つの際だった大きな特徴があります。

それは一つは本疾患が航空機による患者の移動によ り世界に拡散しているということであり，もう一つは 多くの国において，まずは院内感染という形で感染が 拡大しているという事実であります。すなわち SARS が日本国内に入ってくるときの水際は, 空港と病院だ ということになるわけです.

\section{(スライド 4$)$}

ところが, 最初の水際である空港の検疫で $100 \%$ ブ ロックすることは不可能であります。なぜなら潜伏期 間の場合は引っかけることは不可能ですし, 解熱鼡を 使用したり，嘘をついたりした場合には簡単にすり抜 けられてしまいます.すなわち SARS 制圧の最も重要 な水際は病院であり, 最初の患者が発生したときに, 院内での二次感染を起こさずに制圧することができる のかが最大の鍵となるわけです.

\section{(スライド 5)}

これはSARS アウトブレイク初期の香港とベトナ ムのSARS の累積患者数の推移をしめしたものです. 両地域はほほ同時にアウトブレイクが起こりました が, 結果は非常に対照的なものとなうたことがおわか りになると思います。ベトナムは流行を局地的におさ えることに成功しましたが, 香港では感染が市中に拡 散してしまい，コントロールが非常に難しい状況に なってしまったことが分かります。この両地域の対照
的な動向はSARSがもしも日本国内に入ってきた場 合に初期の封じ込め対策がいかに重要であるかを物 語っているように思います。

(スライド 6)

次にSARS の感染経路に関する知見について簡単 にご紹介します.

(スライド 7)

SARS の感染力についてはシンガポールのスーパー スプレッダーの報告があります。

入院後 6 日間は全く感染防御をしなかったため, 多 くの人が暴露しました，その結果，接触した医師の $12.5 \%$ ，看護婦の $30 \%$ ，隣接患者の $8.3 \%$ ，見舞いの家 族友人の $30 \%$ に感染させています.

通常の SARS の患者は 2 3 人程度にしか感染を広 げず， CDC の定義では 10 人以上に感染を広げた患者 をスーパースプレッダーと定義しており，本症例は感 染力の強いスーパースプレッダーであります．ところ が特記すべきことはこのような患者であっても，その 後の感染防御対策により二次感染が起こらなかったと いう事実であります.

(スライド 8)

SARS ウイルスと同じ仲間であるコロナウイルスが 通常は環境中では 3 時間くらいしか生存できないのに 対して, SARS ウイルスが環境中でしぶとく長時間生 存するという事実が明らかになってきました。これま での疫学デー夕はSARSが飛沫感染を主体として感 染が拡大していることを示していますが，特に下痢便 中でウイルスが 4 日間も生存するところから考える と，環境表面を介した接触感染を起こしうるポテン シャルを十分に持っていることが示唆されます.

(スライド 9)

SARS の感染経路を考える上で非常に参考になる データが Lancetに掲載されています。これはSARS 患者さんに濃密な接触をした後，SARSに感染してし まった 13 例の医療従事者を含む合計 254 人の医療従 事者を対象に，患者と接触時どのような感染防御をし ていたかをまとめたものです.注目すべきは 2 点です. 
一つは, マスク, ガウン, 手袋, 手洗いをすべて行っ た 69 例では感染は 1 例も認められなかった事です.二 つ目は多変量解析で感染防止に有意に関連していたの はマスクの着用だけであったのですが，サージカルマ スクを着用していた 51 例では 1 例も感染者がでてい ません.これは間接的ではありますが, SARS の空気感 染はないか，あるいはあってもかなり稀であろうとい うことを示していると思われます。

(スライド 10)

以上より SARSの院内感染対策のイメージをまと めるとスライドのようになると思われます. unknown disease でありますので，もちろん飛沫，接触，空気感 染対策の全てを行うわけですが, 最も重要なのは飛沫 感染対策であり, 空気感染対策の重要性の比率は恐ら くは低いかもしれないということであります。

(スライド 11)

次に院内感染対策の基本概念についてです.

(スライド 12)

まずSARS で最も重要な感染経路と思われる飛沫 感染を防ぐ方法ですが，これにはまず，マスクを着用 すること，そして距離をとることが最も重要でありま す，咳唻時には患者にしっかり口を押さえてもらうこ と，そして風向きに注意し患者に対して自分が風上に いるように意識することが重要であろうと思われま す.空気の流れによっては飛沫の到達距離を延長させ, かえってリスクが高まる可能性があることも念頭に置 く必要があろうかと思われます。

(スライド 13)

接触感染を防ぐには，手袋とガウンを着用するのが 基本ですが，污染した手袋であちらこちらを触ってし まうことは絶対に避けなければなりません．手袋をし ていても手は污染されていると認識することが重要で あり，手袋を脱いだら良く手洗いをすること，そして 擦式アルコールを有効に活用することが大切です。ま た污染区域からの物品の持ち出し，例えばカルテや問 診票を持ち込んだり，持ち出したりすることは絶対に しないようにしなければなりません．個人的にはこの 接触感染対策が最も破綻しやすく注意が必要であると 考えています。

(スライド 14)

空気感染対策については，N95 マスクを使用するわ けですが，顔面にフィットしていなければ意味がない わけで適正に使用することが大切です，病室の換気状 態が常に適正であることの確認や，飛沫核を発生させ
ない工夫を行うことも大切になってきます.

(スライド 15)

最後に強調したい重要事項は以下の通りです.

とにかく手を消毒すること，そして手を消毒するま では自分の顔を含めどこも触ってはいけないと言うこ とです.

またPPEをしていても感染源との接触は最小限に すべきでしょう。すなわち患者とはできるだけ距離を とり, 一緒にいる時間は最小限にするべきだというこ とです．またPPE は污染されていますので，それを脱 ぐときに污染がおこる危険性が高いことを認識してお く必要があります。

(スライド 16)

それでは院内感染対策の実際について国立国際医療 センターの取り組みをご紹介します。

(スライド 17)

SARS は非常に感染力の強い感染症であります.と ころがもっと重要なことは, これだけ感染力が強い感 染症であっても，ガウン，手袋，マスクといった感染 防御対策をきちんとすれば，二次感染を起こさずに制 御可能であると言うことです.つまり SARS の院内感 染対策で最も重要になるのは疑い患者のトリアージに なるわけです.

初診時および再診時の受付の時点でいかに速やかに 疑い患者を見つけるかが勝負になると思われます.

(スライド 18)

まず初診受付ではこのような質問票を配布し，渡航 歴や症状についてチェックしています。

(スライド 19)

再診患者さんの場合は，受付を介さずにこういった 自動受付機で再診受付をしてしまいますので, 機械の 前にも揭示を行っています。

(スライド 20)

以上の揭示をやっても見忘れて，通り過ぎてしまう 可能性があります.そこで待合い室にも揭示を行って, 患者さんがもしも SARSの可能性があると思う場合 には，看護婦に申しでてもらうようにしています。

(スライド 21)

日本語の読めない患者さんもいるので, 外国人向け にこのような英語バージョンも必要であろうと思われ ます。

(スライド 22)

実際の SARS 患者さんは中国，台湾が多いわけです から, 中国語のバージョンも作成し, 院内に掲示して 
います。このようにして SARS の可能性のある患者さ んを早く見つけて，すなわちトリアージを行って速や かに患者さんを適切な場所に誘導することが重要であ ります.

\section{（スライド 23）}

疑い患者が発生した場合にはトリアージ室に速やか に誘導しなければなりません.

患者さんにはすぐサージカルマスクをしてもらい, 最短距離でトリアージ室に移動してもらいます。サー ジカルマスクがすぐに準備できない場合には，ハンカ チやペーパータオルでとりあえず口を覆って頂く，こ れも重要な対策であります．污染を拡大しないように トリアージ室へは最小限の移動距離で移動することに も配慮しなければなりません。

(スライド 24)

患者は初診外来で見つかるかもしれないし, 夜間救 急で見つかるかもしれないし，さまざまなシチュエー ションで発生するわけです，故にそれぞれの場合に誰 が責任をもってどういう手順で対処するのかを明確に するマニュアルを作成しておく必要があります。

\section{(スライド 25)}

これは国立国際医療センターの対策マニュアルの一 つです.

夜間休日に救急受付に患者が発生した場合の患者誘 導の手順と，その場合の搬送責任者を明確にしてある ことが重要なポイントです。これは夜間休日の場合で すが，その他にも平日の初診外来や，平日の外来診療 室で見つかった場合など，さまざまなシチュエーショ ンを想定して，そのマニュアルを作成し，手順と搬送 責任者を明確にしておくことが非常に重要であると思 います。

(スライド 26)

トリアージ室までの搬送経路もどこで患者が発生し たかで, 経路を定めておき, 関係部署に配布, 周知し ています。

(スライド 27)

そのほかにもさまざまなシチュエーションが想定で きます。

たとえば，患者が呼吸不全で救急搬送されてくるか もしれないし，1歳未満の小児や妊婦の患者が発生す るかもしれないし，場合によっては患者さんが隔離さ れることを恐れて, SARSの可能性があることを言っ てくれない可能性もあるわけです.

(スライド 28)
まず呼吸不全で緊急搬送されてきた場合には問診票 でのトリアージなど不可能ですし，これが万が一 SARS だった場合には感染のリスクが極めて高く, 特 に挿管時にリスクが高いことが知られています。これ に対応するためには, 呼吸不全例の救急ではマスク着 用を必ず行い，挿管時には N95 およびゴーグルの着用 が今後はルーチンに推奨されるかもしれないと個人的 には考えています。

(スライド 29)

小児や妊婦の患者が発生する場合が想定できますの で，対策には必然的に婦人科や小児科医師の協力が不 可欠になります。 もちろん, 看護部, 放射線部, 検查 部, 救急部, 事務などいろいろな所の協力が必要となっ てきます.すなわち院内 SARS 対策は病院全体を巻き 込むものでなくてはならないといえます，全員で対策 を考えていかなくてはならないということです。

\section{(スライド 30)}

また患者が自分がSARSの可能性があることを いってくれない場合にはトリアージが不可能であり, そういうことも現実には起こりえるのだろうと個人的 には考えています。トリアージの時点で患者を取りこ ぼすと，院内感染が発生し，破綻してしまいます。ど ういう対策が考えられるかということですが, 今後検 討すべき診療のスタンダードとして，咳をする患者に は全員マスクを配布し, 診療医師は全員マスクをし, 患者ごとに手の消毒を行うということを常識として ルーチンに行うべきなのではないかと個人的には考え ています。これまでにも実際には麻疹，結核，水痘な ど空気感染や接触感染する病気が存在しており, 待合 室で他の患者さんとの接触は起こっていたわけで，こ れによる院内感染も現実に起こっているわけです. SARS の院内感染対策を考える一方で，これをきっか けとしてこのような当たり前の院内感染対策をスタン ダードなものににしていく必要があるのかもしれませ ん.

\section{（スライド 31$)$}

国立国際医療センターの感染症病棟とトリアージ室 です。ここでトリアージを行い，もしもSARSらしい とういことになり, 入院の必要があれば最短距離で感 染症病棟に移動できるように配慮しています。

(スライド 32 )

トリアージ室での対応で重要と思われる点をまとめ ました。

まず 2 人以上のチームで診ることがミスを防ぐ上で 
重要であると思われます。一人が中に入り，室内の電 話で外部のスタッフに連絡をとることでトリアージ室 からの不必要な出入りを避けることが重要になりま す．カルテや問診票は内部に持ち込まないようにする こと．そして診療マニュアルを作成し，すぐに参照で きるようにするなども工夫も必要であると思われま す.

(スライド 33)

国立医療センターではこのように毎週時間割を組ん で，トリアージ診察の責任者を決め，なるべく 2 人以 上のチームで対処できるようにしています.

(スライド 34)

このようなマニュアルをトリアージ室内に配備し，

患者さんが入室してから，診療を終え退出するまでの 手順を，チェックリストを確認しながら診療ができる ようにしています.

(スライド 35)

トリアージ室での PPE です.ディスポの術衣に着替 え，N95 マスクを着用して，ガウンキャップをかぶり， その上から黄色ガウン，フェイスシールドを着用しま す。これで体表面の全てを覆うことができます。手く びや首もとが露出していないこと，ひもの結び目を前 に持ってくることがポイントになります．飛沫，接触 感染を防ぐために, 露出皮痛を極力なくすことが重要 であろうと思われます。このような装備をしますと全 部ディスポとした場合，コストは約 2,500 円となりま す.

\section{(スライド 36 )}

診療後はPPE を脱ぐわけですが，PPE 自体は污染 されているわけですから，脱ぐ時に污染が起こる可能 性があるわけで，その手順に関するマニュアルを作っ て徹底する必要があります，手袋やガウン，フェイス シールドが最も病原体に污染されている可能性がある ので，最初にこれをまず脱ぎ捨てることが原則です． 手袋を脱いでからマスクやゴーグルを脱ぐことになり ます。一連の作業の間は，アルコール消毒を頻回に有 効に行うことが污染事故を防ぐのに重要です.

\section{（スライド 37）}

まず手袋ごとアルコールで消毒してから，引きちぎ るようにガウンを脱ぎ，污染されていない部分が表面 に来るように，輷返すようにはぎ取るのがポイントで す。その後，ガウンキャップを取ります。

(スライド 38)

ここで手袋を捨てて，アルコールで手を消毒してか
らマスクを捨てます。念入りに最後にもう一度アル コールで手を消毒してから退室することになります。

（スライド 39）

一部の地域では，コストなどの問題からマスクの再 使用を検討している病院もあるようですので，それに 関して簡単なコメントを致します。

まずSARS は接触感染がかなりリアリティのある 感染経路でありますので，マスクの再使用はやむを得 ない最終手段と心得てください。

ちなみに現時点で WHO のガイドラインではマスク の再使用についての記載はありません．

CDCではN95の上にサージカルマスクをかぶせ て，N95 を再使用する方法を提案していますが，それ でもマスク表面は污染されていることを前提として手 洗いをしっかり行うことが強調されています。

そして污染したと思ったら躊躇せず必ず捨てること であります。

(スライド 40)

トリアージ室で診察し，もしも SARS の可能性が高 いということになると入院対応となりますが，入院病 室はやはり，陰圧個室で手洗い，風呂場がついている のが必須条件であろうと思われます。この場合，院内 感染は絶対に避けなければならないため，リスクの高 いPPEの再使用は入院管理の場合では避けるべきで あると考えます。

入室する医療従事者はPPEの取り扱いについて熟 知している必要があります。窒者および入室回数も 最小限にすることが重要です。また SARS 専門医とい うのはいないわけで，通常業務に上乗せされる形で仕 事をすることになります，通常業務は減ることはない わけですから, SARS 入院が入ると, 担当者は疲労しや すく，そして担当者が疲労するとミスが発生しやすく なると思われます，通常業務を他の従事者で肩代わり するなどして，担当者の過労を避ける工夫も，感染対 策の破綻を防ぐための重要な取り組みであろうと考え られます。

（スライド 41）

国立国際医療センターの入院病棟での装備です。卜 リアージレベルとの違いはガウンと手袋がそれぞれ二 重になっていることと, シューカバーとブーツを着用 している点です.

(スライド 42 )

最後のスライドです.

感染制御にもっとも重要なファクターはマスクでも 
手袋でもなく, 知識でありテクニックであることをこ こで再び強調したいと思います，どんなに厳重な装備 をしても知識がなければ簡単に破綻してしまいます. そしてたった一人のミスによる污染でも全員がリス
クに曝されることになりますので, ひたすら教育が重 要であり, 従事者は最小限にするべきであるというこ とです.

以上です．御静聴どうもありがとうございました. 


\section{SARSの院内感染対策}
1. Introduction
2. 感染経路に関する知見
3. 院内感染対策の基本概念
4. 院内感染対策の実際

国立国際医痖センター エイス治療研究開発センター 照屋 勝治

\section{SARS制圧の水際は病院である}

最初の水際:空港での検疫で $100 \%$ ブロックするのは不可能

潜伏期間ですり抜ける

解熱剂ですり拔ける

嘘をついてすり拢ける

最初の患者が発生した時、院内での 二次感染を起こさずに制圧できるかが鍵

\section{スライド 2}

\section{SARSの院内感染対策}

\section{Introduction}

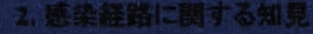

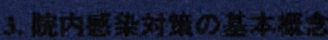

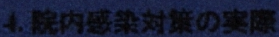

\section{スライド 3}

\section{SARS}

\section{ニつの際だつた大きな特徴}

○航空機での患者の移動により世界に拡散している ○多くの国で院内感染という形で感染が拡大している

\section{スライド 5}

\section{香港とベトナムのSARS累積症例数}

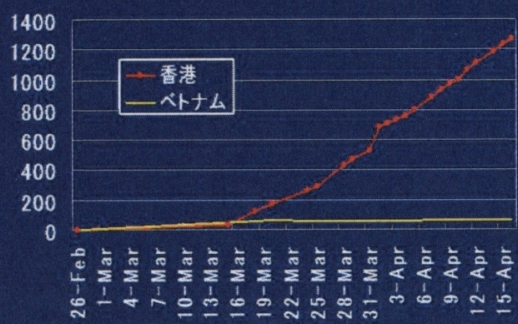

スライド 6

\section{SARSO院内感染対策}

2. 感染経路に関する知見 
スライド 7

\section{SARSの感染力}

(Emer Infect Dis 9, 713, 2003)

○シンガポールの20例のクラスターの検討

(スーパースプレッダー)

Index caseが入院して6日間はPPE(-)であつた。

接角した医師 $1 / 8(12.5 \%)$, 看護婂 $9 / 30(30 \%)$,

隣接患者 $1 / 12(8.3 \%)$,

見舞いの家族友人 $9 / 30(30 \%)$ か感染した。

N95マスク含むPPEて以後の感染者は全くなし。
スライド 10

\section{SARSの院内感染対策}

標準予防策十飛沫感染予防策

$+$

接触感染予防策

$+$

空気感染予防策

\section{スライド 8}

\section{SARSウイルスの} 環境中の生存期間

他のコロナウイルスよりも環境表面で長時間生存

プラスチック乾燥表面で48時間 下痱便中では怛間生存

環境表面を介した接蚛感染の可能性がある。

\section{スライド 9}

\begin{tabular}{|c|c|c|c|}
\hline \multicolumn{4}{|c|}{ SARS刘策に必要なPPEは？ } \\
\hline Protective measures & $\begin{array}{l}\text { Infected Staff } \\
(\mathbf{n}=1 \mathbf{3})\end{array}$ & $\begin{array}{l}\text { Yon-Infected } \\
\text { Staff }(n=241)\end{array}$ & p \\
\hline Mask & $2(15 \%)$ & $169(70 \%)$ & 0.0001 \\
\hline Paper mask & 2 & 26 & 0.511 \\
\hline Surgical mask & 0 & 51 & 0.007 \\
\hline N95 mask & 0 & 92 & 0.0004 \\
\hline Gloves & $4(31 \%)$ & $117(48 \%)$ & 0.364 \\
\hline Gowns & $0(0 \%)$ & $83(34 \%)$ & 0.006 \\
\hline Hand-washing & $10(77 \%)$ & $227(94 \%)$ & 0.047 \\
\hline All measures & $0(0 \%)$ & $69(29 \%)$ & 0.022 \\
\hline
\end{tabular}

スライド 12

飛沫感染を防ぐには ... マスクを着用 距離をとることが大事 (2m以上離れる) 咳䎥時はしっかり口を押さえてもらう 風向きに注意一風上を意識する （下手な換気は飛沫到達距離を延長） 
スライド 13

接触感染を防ぐには

手袋、ガウン着用。

污染した手袋であちこちを触らない

手袋をしていても手は污染されていると認識

擦式アルコールの有効、頻回使用

污染区域からの物品の持ち出しは絶対にしない

“接触感染対策が最も破綻しやすい”
スライド 16

\section{SARSO院内感染対策}

4. 院内感染対策の実際
スライド 14

\section{空気感染を防ぐには・.}

N95マスクを適正に使用する

病室の換気状態は常に適正であること

飛沫核を発生させないエ夫 （ネブライザーを使用しないなど）

\section{スライド 17}

疑い患者のトリアージが最も 重要である。

初診時、および再診時の受付の時点で いかに速やかに疑い患者を見つけるか がポイン。
スライド 15

\section{強調したい重要事項}

○ひたすら手の消毒、消毒、消毒！(擦式アルコールで) そして手洗い。

○完全に手を消毒するまで、絶対にどこも触らない

OPPEをしていても、感染源との接触は最小限に(距離、時間)

OPPEは脱ぐ順番が柾めて重要であることを知る
スライド 18

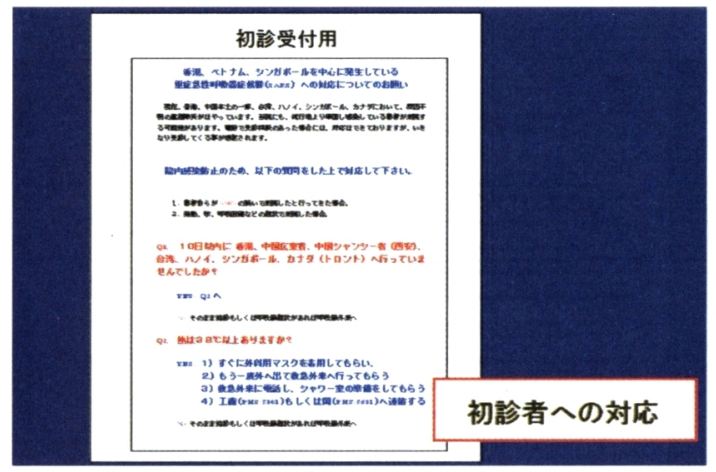


スライド 19

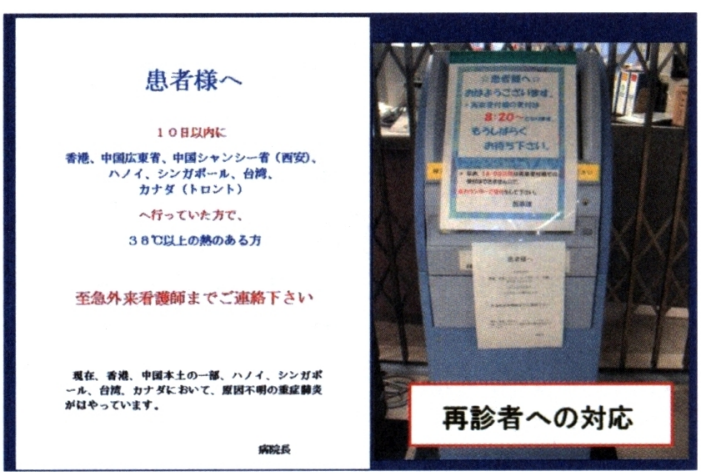

スライド 20

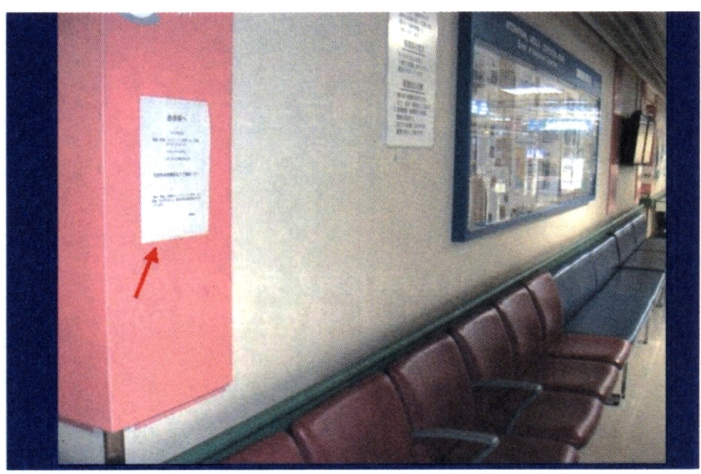

スライド 21

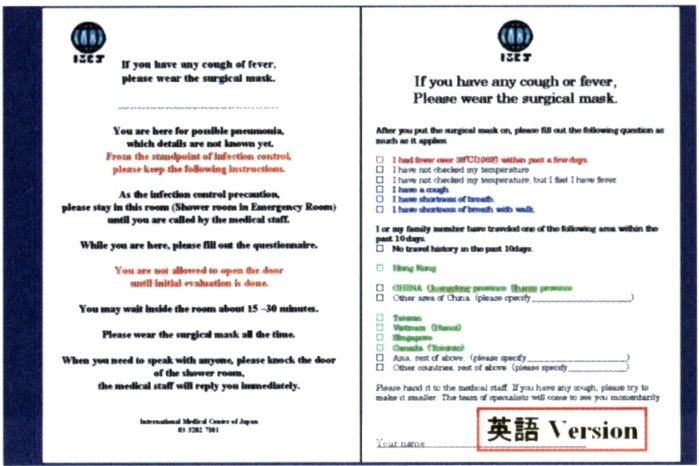

スライド 22

\section{致患者}

最近 10 大以内到過中國(包括香港)，台浩，非律筫，新扣坡，

或者与上述地區的來人見過面,
出現 $38^{\circ} \mathrm{C}$ 以上發熱的人

請立即与門稿護士長聯係

\section{トリアージ室への誘導}

疑い患者にはすぐサージカルマスクを

(ペーパータオルやハンカチでロを覆うのもOK)

污染を拡大しないよう、移動距離は最小限に。

スライド 24

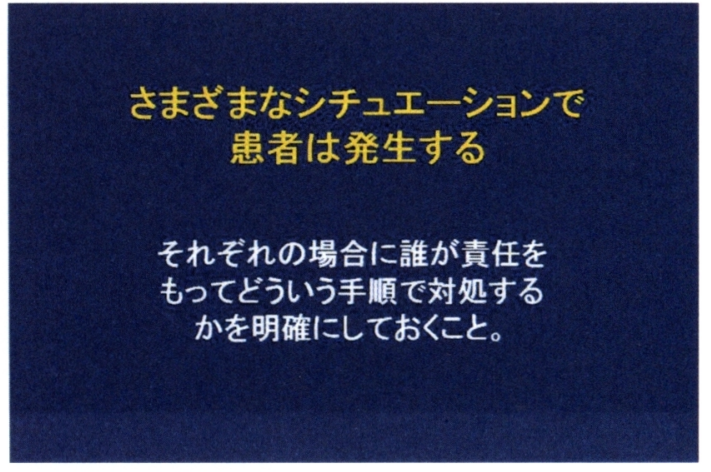


スライド 28

夜間休日

SARSマニュアルを萭たす患者さんが敕急受付に来院 職員はN95 および 手袋を装着する。

患者さんにサージカルマスクを装着して頂く。

一旦敕急部の外へ出てもらい

$\mathrm{ACC}$ 当直医人連絡（当直表参照）

救急外来看護師 2106または2107ににも連絡する

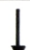

当直医の判断で酦送経路を決定する

较送責任者 医師

洼）時時にはメール以上維んること。

スライド 26

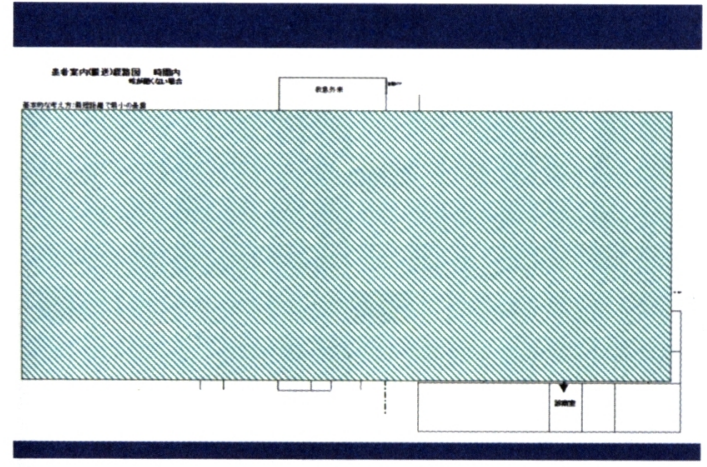

スライド 27

その他の想定されるシチュエーション

○呼吸不全で救急搬送されてくるかもしれない

一小児や、妊婦かもしれない

OSARSの可能性を言わないかもしれない... ! !

\section{○呼吸不全で緊急搬送されてくるかもしれない}

問診票などでのトリアージなど不可能

SARSであった場合は感染性が高い可能性がある

特に挿管時に感染のリスク高い

呼吸不全例の救急ではマスク着用を必ず行う

挿管時にはN95およびゴーグルの着用

\section{スライド 29}

の小児や娃婷かもしれない

院内のSARS対策は婦人科や 小児科の医師の協力が不可欠

診療全体では看護部、放射線部、検査部、 救急部、事務の協力も必要

院内SARS対策は病院全体を

巻き込むものでなくてはならない

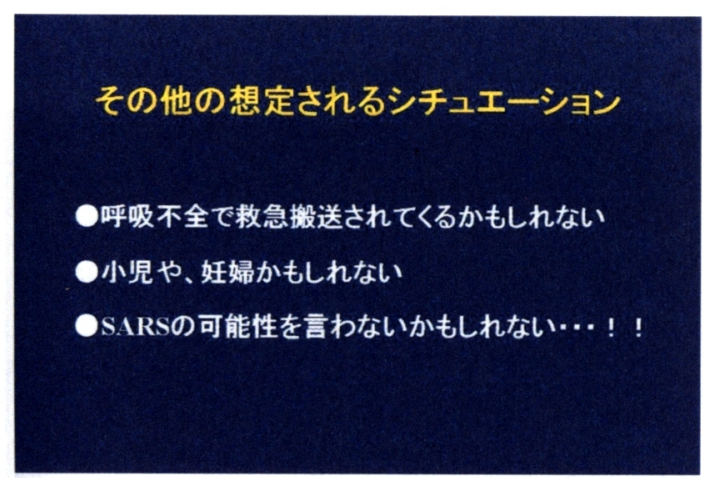

スライド 30

OSARSの可能性を言わないかもしれない

種々の対策でも疑い患者を取りこぼす可能性はある

検討すべき今後の診療のスタンダード?

咳をする患者には全員マスクを配布する 診療医師は全員マスク、患者ごとの手の消毒を行う 
スライド 31

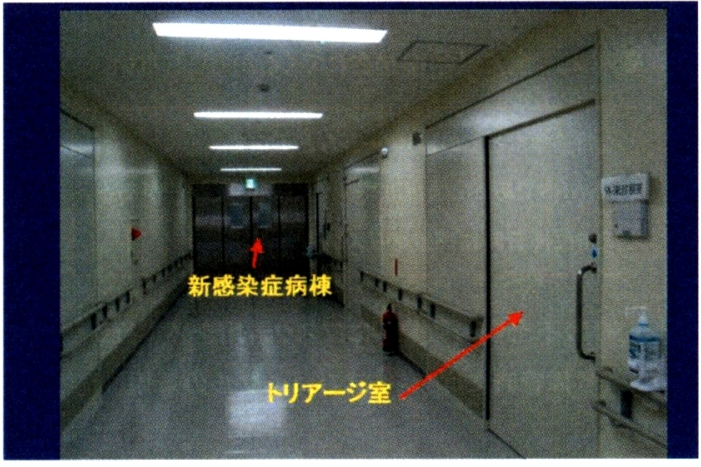

スライド 32

トリアージ室での対応

2人以上のチームで診る

トリアージ室内への電話の設置

不必要な出入りを避ける

物品は持ち出さない(カルテ、問診票)

マニュアルを作成し、すぐに参照できるように する。

スライド 33

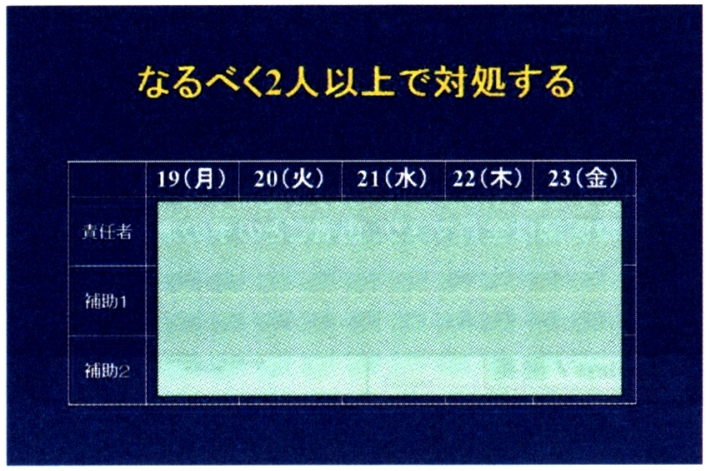

スライド 34

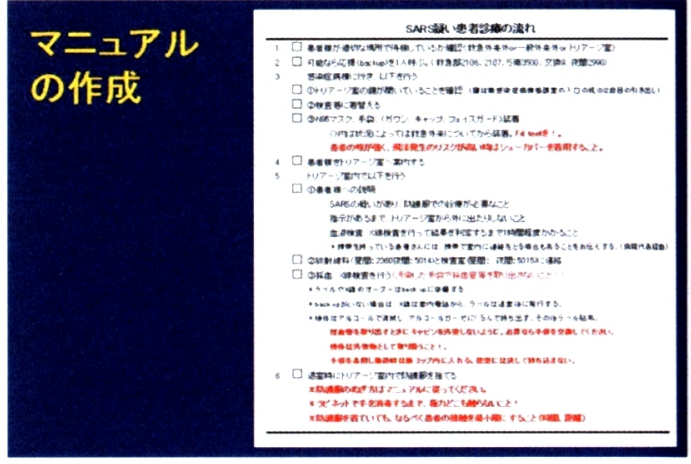

スライド 35

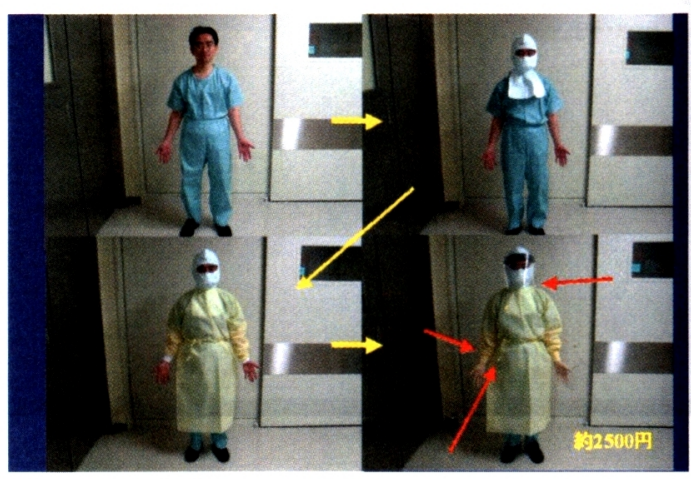

スライド 36

\section{PPEの脱ぎ方}

○脱ぐ順番がとても重要

○表面の手袋、ガウン、フェイスシールドが最も污染

一 これらを最初に脱ぎ捨てること

○マスクやゴーグルを触る前に、手袋を唅てること

○擦式アルコールを頻回に有勃に活用すること 
スライド 37

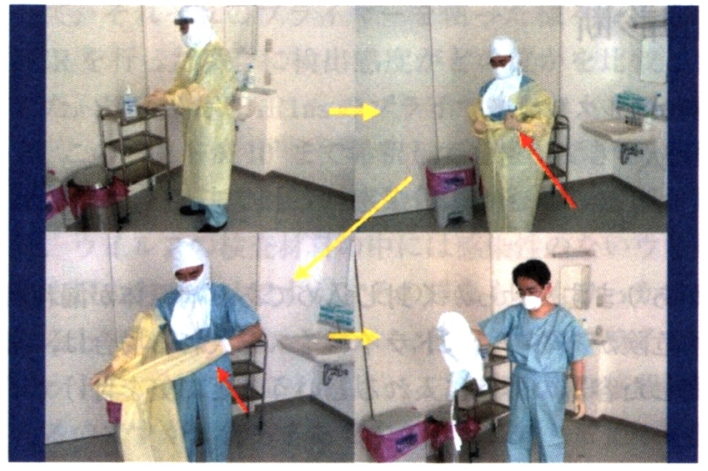

スライド 38

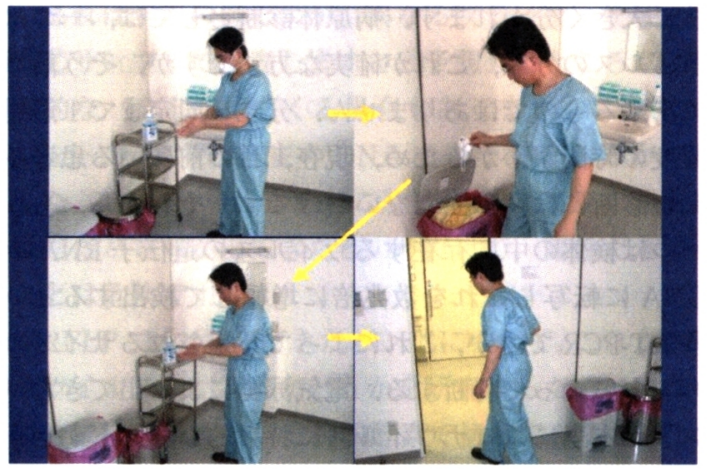

スライド 39

\section{マスクなどの再使用について}

やむを得ない場合の最終手段と心得ること。

WHOのガイドラインでは再使用の記載なし。

、95の上にサージカルマスクをかぶせる方法(CDC)

圈人専用とし、所定の畦所に片づける。

再装着時はマスク表面に感染性物筫がある前提を意識する。 再装着後、手を洗う。

污染したと思ったら訾踵せず唅てること。
スライド 40

\section{入院病室での対応}

○陰压個室。手洗い、風呂場のついている のが必須条件。

○PPEの再使用は澼けるべき。

○入室する医療従事者はPPEの取り扱いについて 熹知していること。入室者およひ入室回数は最小 限にすること。

○担当者の過労を䠰ける?？
スライド 41

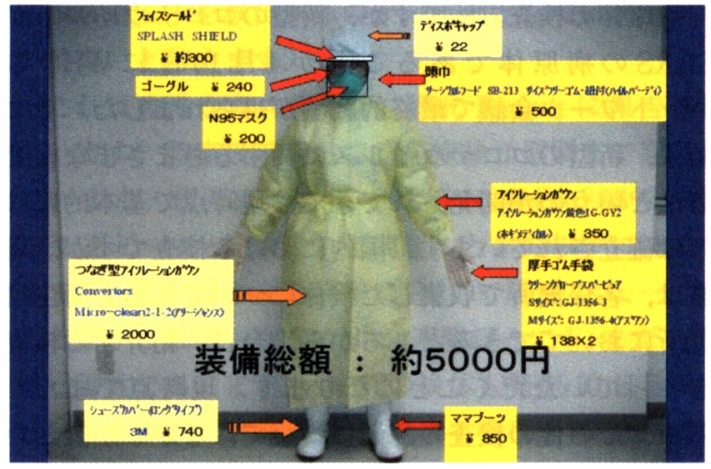

スライド 42

\section{感染防御に最も重要なファクター}

マスクでも手装でもなく、知識でありテクニックである。

たつたー人のミスによる污染でも全員をリスクに曝す

教育、教育、教育！。従事者は最小限に。 


\section{ウイルス学的診断}

国立感染症研究所村山分室ウイルス製剤部

田代眞人

感染研の田代でございます. 今日は検査のことだけ に話を絞ってお話致します.殆どの方は, 今回の SARS の問題に関して, 最初はパラミクソウイルスが病原体 だとメディアで報道されたのに，いつの間にコロナウ イルスと変わってしまったんだと, パラミクソウイル スはどうなってしまったんだろうと疑問を持っておら れるかと思います，時間がありましたら，それについ てもお話したいと思います。

病原体の検查方法ですが, 新型のコロナウイルスが SARSの病原体であることが4月 16 日にWHOの ネットワーク会議で最終的結論が得られました。 その 結果, 新型のコロナウイルスに関するさまざまな検査 方法というのが開発されてきて, 現時点で基本的には ほほ確立されています，国内における検查ですが，現 在は, 各保健所で収集した検体について各地方衛生研 究所においてできるところから, 今日, 紹介する検査 をやっていただくことになります，現時点でまだ， PCR, その他の検査の評価について, なかなか難しい 現状で，その結果について国立感染研でダブルチェッ クをすることになっております。都道府県からの依頼 検查として感染研に送ってこられる検体で, 検者の対 象となるのはSARS の可能性例すべて, および疑い例 については地衛研で PCR もしくはウイルス分離の設 備がなくて実施出来ない場合, それから PCR 陽性の場 合のダブルチェック，ウイルスが分離された場合のウ イルスの同定のために，検体を送っていただいており ます．また，患者のペア血清について，新型コロナウ イルスに対する seroconversion を確認する.

検体の送付方法ですが，現時点で新型コロナウイル スの危険度がどの位であるのかが確定しておりません ので, BSL のレベル 3 に相当する対応を取るというこ とになっています.WHO の規定と同じょうに三重で, パッケージに入れて送る．郵送する場合はこれです。 直接検查機関に運ぶ時はボックスに入れて三重で運ん でいただいたおります。この時，気をつけることは， 密閒した容器の中にドライアイスを入れないことで す. 室温でドライアイスは気化して, 爆発する可能性
があります．せっかく封じ込めてある病原体が漏れ出 す危険があるので, ドライアイスを入れる場合は, 密 閉した容器の外側に入れるということに気を付けて下 さい.

検査方法の流れですが，臨床検体としては鼻咽頭の 拭い液, 吸引液, 気管支肺胞洗浄液, 便, 血清, 尿. 剖検の場合の様々な組織おもに肺。これらを用いて病 原体の診断と血清学的に抗体を調べる，その二つの方 法に大きく分かれます．病原体診断としては，一つは ウイルスの分離，これが確実な方法ですが，そう簡単 に出来るものではありません．分離・同定まで 1 週間 程度の時間がかかるため, 現在, 目の前にいる患者さ んの診断には役に立たないわけです．それから，もう 一つは検体の中に存在するウイルスの遺伝子 RNA を DNA に転写しこれを数兆倍に増幅して検出するとい う RT-PCR ですが，これによって想定されるサイズの バンドによって判断する．電気泳動により出てきたバ ンドが本当にコロナウイルスに特異的なバンドかどう かをチェックしなくてはならないわけですが，ご承知 のように PCR は非常に実験室内の交叉感染もありま すし非特異的に偽陽性に出る場合もあります。そこで RFLP によって遺伝子産物を確認する，もしくは塩基 配列の決定をやるということになっております。一方， ウイルスが分離された場合には，培養上清について電 顕でコロナウイルスの粒子を確認する，もしくはRTPCR でこちらと同じょうに遺伝子を確認する.これら に対して血清学的な診断では, 特異抗体を検出するわ けですが，方法としては蛍光抗体法，中和抗体測定， ELISAの3つが現時点で確立されております.それぞ れ色々と問題もあり, SARS の確定診断のための根拠 とはなりえません."

これが最初の PCRの話ですが, WHO の HPでは

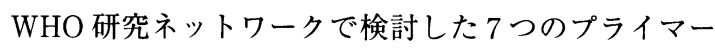
が紹介されています。この中で, どのプライマーが一 番感度がいいのかというようなことを独自に検証致し ました。そうしますと，ここに 7 種類のプライマーが 並んでいますけれど, 約 $10^{7} / \mathrm{ml}$ の感染価のある香港で 
分離された新型のコロナウイルスを 10 倍づつ希釈を して，それぞれのプライマーを使った様々な条件で PCR を行った場合に検出感度がどの位かを比較しま した. SAR1s と SARlas のプライマーセットを用いる

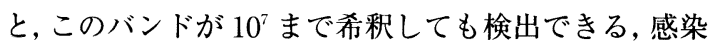
価をプラック法で計った感染価よりむしろ感度が高 い. ウイルスの検査材料の中には感染性のないウイル スも沢山あるわけですが，その様なものもひっかけら れるということです.それから,他の二つのプライマー セットについても,これに比べると感度は 10 倍程度落 ちるのですが，まあまあです，それに対して他の研究 グループから紹介されているプライマーの幾つかにつ いては，ほとんど使い物にならない物もあるというこ とで, WHO の HP だけを信用して PCR を行うととん でもない結果になる可能性もあります.

これは実際の例ですが, 異なるプライマーを使って 同じサンプルで検査しますと, 予想外のところに非特 異的なバンドが出てくる場合もあります。これを sequence しますと宿主の DNA 由来であると分かりま した.こういう事はよく起こりますので PCRの場合に はただバンドが出てきたというだけで，陽性だという ことは危険です.

RFLPですが, 出てきたバンドについて,これがコロ ナウイルスのバンドかどうかを研究するために，この 場合には KLU1 という制限酵素で切ってやると, この 様な 2 本のバンドに分かれてくる. 確かにこのバンド は, 新型コロナウイルスに特異的なバンドであろうと いうことが確認できるわけであります。

PCR で検出されたバンドについて sequence をやっ た結果ですけれど, CDC から報告されているその領域 の sequence と 100\%一致しているというょうなこと が分ってきています. sequence をやれば, 確かにこの バンドがコロナウイルス由来であるかどうかが一目瞭 然に確認できます。しかし全部の検体について，これ をやるのはなかなか大変な仕事量になります.

細かくて申し訳ないのですが，幸いなことに国内で は陽性の患者はいなく, 陽性の検体がありません.我々 のところでは, WHOの西大平洋地域の reference laboratory をやっているので, 今まで 100 検体以上が 各国から送られてきていて検查致しました。 その中の ごく一部を示したものですが, PCR は陽性だがウイル スは分離できないというものがあります。また逆に, ウイルスは分離できるけれど PCR は陰性であるとい うものもありました。 ということで, 今の段階では
PCR の感度というものは，大体のところ $70 \%$ ～ $80 \%$ くらいであろうと考えられます.ですから PCR で陰性 であったからといって, 感染を否定してはいけない. また，陽性であっても，先ほど言いました様に交叉污 染や非特異反応の可能性がありますので, それだけで 陽性といってはいけない,ということで, 現時点では 残念ながら PCR の結果をもって診断に直接結び付け ることは出来ない状況であります.

これはパスッール研究所と我々のグループが共同研 究としてやったものですが, 様々な検体について, 色々 なプライマーを使った結果です。これが先ほども申し 上げました一番感度のいいプライマーです。これにつ いて陽性率をみてみますと, いずれにしても上気道の サンプルについては 20〜50\% でそれほど高くない.一 方, 便からはほぼ100\%であり便から PCRによってウ イルス遺伝子を検出するのが, 感度としては検出率が 一番高いと言えます.

これは香港からの報告で, 既にLancetに報告され ています. 発症後の病日で, 発症後 3 週間まで記され ています。咽頭ぬぐい液では第 10 病日の $95 \%$ から $75 \%$ をピークとして, 3 週間経つと半分以下に減って きます。これはかなり高率に PCR で陽性です．一方, 便ですがこれは $100 \%$ です. 3 週間経っても，まだ $70 \%$ 近く陽性であります.いずれの検体も発症 10 日目頃が ピークですが,これ以前の発症第 1 病日から 10 日間の あいだは, 上気道の材料からは殆ど陽性に出てきませ ん. 検出されても $20 \%$ 位の陽性率であります.一方, 便のほうは，非常に長期間陽性です．潜伏期間を含め て, 発症後, 最高 35 日まで検出されており, 便の中で かなりの高率でウイルスが見つかっています．ですか ら先程から SARS の感染が飛沫感染であろうとなっ ていますけれども, 確かに発症した後の感染源として は飛沫が一番大きな原因だと思いますが，便の中に排 泄されるウイルスも感染源として大事なのではないか ということが強く疑われています．対策についても飛 沫感染に対する対策だけでは不十分ではないだろう か, 潜伏期および熱が下がって回復して 10 日すれば退 院していいと言う WHOのガイドラインがあります が，その後も気を付けなければいけない可能性があり ます．一方，尿の中にも $50 \%$ ないし $20 \%$ 位ウイルス が検出されてまいります．血液中にも検出されます. 即ち全身感染を起こしていると言うことです.

次にウイルス分離ですが, 先ほども言いましたよう に, これは現時点でバイオセーフティ・レベル 3(BSL- 
3）のレベルに準じて作業することになっていますの で, P3 の施設でウイルスの分離を行なわなければいけ ない.このような設備の無い研究室では，このウイル スを扱うことはできません.

現在のところ, 二つの細胞核がこのウイルスに対し て感受性が高いということが言われていますが，我々 のところでは, Vero E6 という Vero 細胞の一つのサ ブラインを使っております。これを現在，各地方衛生 研究所へ配っております。このようなコントロールの 細胞にこのウイルスを感染させますと 24 時間目以降 に,このように CPEが出現してきます. 細胞融合が起 こって細胞がどんどん死んでいく.我々のところには, 陽性の検体がありませんが, 香港, その他のところで 見ますと,だいたい 3 日目から 4 日目で $\mathrm{CPE}$ が検出で きると言われています.

この CPEが陽性になった場合に，これが確かに SARS コロナウイルスによって起ったんだと, コロナ ウイルスが分離されたことを確認しなければなりませ ん.そのためには, RT-PCR が一番簡単で感度のいい方 法となります。

次に血清学的診断ですが，これは seroconversion が起って抗体が陽性となってくるまでに時間がかかる ので, 目の前にいる患者には役に立ちません. 3 週間な いしそれ以上の時間が経ってから，回顧的にこの患者 は, このウイルスに感染したかどうかということが分 かるわけです。一方，血清をもちいて抗体を検出する 場合には, 血清検体の中にこのコロナウイルス（先ほ ど申し上げたウイルス血症を起こして全身感染を起こ すウイルス) が残っていますと, 検査する場合非常に 危険である. どの様な処理をすれば血清中のウイルス を不活化できるかということを調べました.これは 56 ${ }^{\circ} \mathrm{C}, 30$ 分という非働化条件ですが, そうしますと, 抗 体活性を損うこともなく, 十万分の一程度に感染を落 すことができます．実質的には，これで殆ど完全に危 険性を無くして安全に血清の検査ができることが分か りました. 以後, 血清診断については, この条件で予 め血清を处理してから検査を行なうということが世界 的に行なわれています.

蛍光抗体法ですが，抗原としては先ほどの細胞にウ イルスを感染させて 16 時間たったものについて,これ を剥がして非感染細胞と混ぜてスライドグラスの上に アセトンで固定します，アセトンだけでは，このウイ ルスの感染性を失活させることができません，そこで 我々はUV 照射を行っています。他の研究所からも
SARS コロナウイルスの不活化には $\gamma$ 線，その他で徹 底的に感染性を無くしてやる必要があることが報告さ れています，血清のサンプルは，先ほど言いました様 に, $56^{\circ} \mathrm{C}, 30$ 分の非働化, 段階希䣋して, ウイルスの 抗原陽性細胞を固定したプレートと反応させて, 間接 蛍光抗体法で調べます，そうしますと，これが急性期 の血清ですが, 40 倍希釈で殆ど何もなってこない，陰 性です。これが 3 週間たった後, seroconversion が起 こった後の血清ですが, 160 倍希釈してもこの程度, 陽 性細胞と反応します。これは中和抗体の結果ですが,

これはウイルスを血清を希釈したものと混ぜて中和反 応を起こさせて, 残った感染価を定量するというょう な方法です．左側が急性期，右側が seroconversion を起こした回復期，この差で 4 倍以上の抗体価の上昇 があれば, seroconversion が起こったと判定されます。

これは香港の患者のペア血清について，これが急性 期, これが 3 週間以上たった後です. 蛍光抗体法と中 和抗体法によって，この 6 人の患者のペア血清につい て調べますと，いずれも，急性期では抗体価が殆ど検 出できないけれども，3 週間以上経つと中和抗体も蛍 光抗体も高い抗体価がもってくるようになる． seroconversion が起こってくる. 雨方が平行して起ってい ることが分かります.

これは ELISA ですが，現時点では ELISA の抗原と しては, 感染細胞をそのまま可溶化して用いており, これを不活化して ELISAのプレートに張り付け, 間 接法の ELISA をやっているわけですが，この方法に ついては, 現時点ではほぼ満足のいく方法が確立され ています。ただ，残念なことに我々のところには多数 陽性の血清がありませんので, カットオフ值の設定に ついて，自信を持って言えないのですが，定性的な意 味で，白黒をつけるという目的では十分であり，現在 でもすぐに使えます，先ほどの蛍光抗体法でも， ELISA 法でも同じなのですが, 現時点ではウイルス感 染細胞を抗原に使っているので，この抗原を調製する ためにはP3 の設備で, 非常に面倒なことをしなくて はならない。そこで遺伝子組換えによって ricombinant の抗原を発現させる系を，今，開発を進めている ところであります.

それから今言ったような検査で，陽性に出た場合に どのように対応するかですが，PCRが陽性に出た場 合, 幾つかのチェックの仕方が WHO から推奨されて います.一つは臨床検体に戻って，もう一回 RNAの抽 出から始めて, RT-PCR を行なう。ささらに restriction 
enzyme できって，予想される位置でバンドが切れる かどうか. 又は DNA の sequencing を確認するという ことをする．それから，もう一つは一箇所で陽性に出 た場合は，その検体を別の研究室へ送って，ダブル チェックをしてもらう．国内では感染研でダブル チェックをやることになっています，プライマーの位 置を変えて, 異なるプライマーセットで再び PCR を行 なう。このようなことによってもチェックできるとい うようなことが言われています．ただこの場合でも， 最初のサンプルにラボラトリーの中で，交叉感染があ りますと，いずれも陽性に出てしまう可能性がありま す。そこを気を付けなくてはいけません. ウイルスが 分離された場合にも，そのウイルスが確かに新型コロ ナウイルスであるか否かを現時点では感染研が現在 チェックをするということになっています.

血清学的な診断に対する対応ですが, 現在, 感染研 では血清学的診断法として, IF, 中和抗体法, ELISA の3つが確立しておりますが, こういうものを，まだ 診断キットとして地方衛生研究所に配るだけのcapacity がありませんので, 残念ながら, こういう事の 最終的な検査は全て感染研で行なうことになります。 この時に，ペア血清を採っていただきたいということ をお願いしております. 現在のSARS の症例定義とい うのは症候診断でありますが加えて SARS コロナウ イルスに対する血清抗体価の上昇が一つ有力な手がか りなっているわけです。これが一応 golden standard と考えられておりますけれど, 抗体の上昇というもの についても，まだ幾つか疑問があります．明らかに SARS の症状を呈して, RT-PCR で何回も検体からウ イルスの遺伝子が検出されているのにもかかわらず, 3 週間 4 週間経っても抗体が上がってこないという ケースが幾つか報告されています。香港では $3.6 \%$, $\mathrm{CDC}$ では $5 \%$ ある。 それが SARS 以外, コロナウイル 感染以外の紛れ込みなのか, それともそういう nonresponder が存在するのか. 又は PCRの陽性結果が laboratory contamination なのか. 色々な可能性が考え られます，そのような問題を解決しなくてはならない ので, 是非ともぺア血清をとって調べておく必要があ る. SARS の疑い例, 可能性例で, 症例定義から言いま すと, 熱が出て, 咳が出て, 外国に行ってきたという くらいですから，インフルエンザなども紛れ込んでし まう可能性があるわけです，今後は SARS コロナウイ ルス感染というものを血清学的に確認できたケースに 限定した様々な検討の必要がある. その為には, 是非
とも血清診断において SARSウイルスに感染した人 なのか，しなかった人なのかを，きちっと分けて考え なければいけない.この目的のために是非ぺア血清を 採っていただきたいと思います.

それから，診断とは直接関係はないのですが，様々 な環境条件において, 今回の新型コロナウイルスの感 染性がどの程度安定であるかということを調べまし た.これは WHO ネットワークの仕事ですが，ここに 上げたのは 4 つ研究所で行なわれたものです．予想 よりもかなりしぶとく，自然環境中においてかなり長 期間にわたり感染性が保たれる可能性があるというこ とが分かりました．下痢便の場合，pH9の弱アルカリ 性ですと 4 日間は感染性が保たれています. 普通の便 の中でも，かなりの時間です．色々なプラスティック 器具などの表面に付けて乾燥状態にしますと, 数日間 感染性が保たれて, 0 にはならない. $4^{\circ} \mathrm{C}$ の低温では 1 ヶ月程度感染性が残るとの報告もあります。一方様々 な消毒剤についても比較的抵抗性が強い. 更に感染細 胞をアセトンで普通の蛍光抗体法をするために, 10 分間～ 20 分間, アセトンで固定しても感染性は無くな らなかったということも報告されております.

現時点ではSARS は, あくまでも症候群として除外 診断です. probable case とその回りに suspect case, もしかしたらその回りに，それにも該当しないもっと 軽いもの (非定型 SARS), 若しくは不顕性感染もある かもしれない，一方，コロナウイルスがSARS の原因 であるということが, 確定してきましたが, SARS コロ ナウイルスの感染症 $=$ SARS ではないということも 段々分ってきました。 コロナウイルス感染だけで, 全 く発症しない例もある. probable case, suspect case の中にもコロナウイルス以外の原因による症例も当然 含まれてきます。 5 月 1 日にWHO が改定した症例定 義では, 疑い例の中でコロナウイルスの検查を行なっ て，一つでも陽性のものがあった場合には，一つ格上 げをして可能性例に入れるというように規定が変わり ました，その為には，この検査方法が信頼性のある方 法でないと困るわけですが, 先ほど言いましたように， 現在の PCR の信頼性が急性期診断には大丈夫だとい うレベルには至っていないという事が大きな問題でそ れに加えて, 初期の検体には, そもそもウイルス遺伝 子が排出されていない点が大きな問題です.

SARS の原因は新型のコロナウイルスだということ が決まったわけですが，その前にパラミクソウイルス が原因として疑われました，特にヒトのメタニューモ 
ウイルスが原因であるということが 3 月後半に報告さ れ広く報道されています。この根拠は, 最初に患者の 咽頭分泌物から, 電子顕微鏡でパラミクソウイルス様 の構造物がみえたという事, それから PCRによっても 咽頭からメタニューモウイルスの遺伝子が検出できた ことです.電顕で最初に見たのがドイツですが, 香港, カナダでは，ほほ 100\% PCR では見つかると報告され ました，一方我々を含めて，その他の研究所は，殆ど が陰性の結果でした。 ということで，メ夕ニューモウ イルスついては疑問が生じました.一方, SARS コロナ ウイルスについては, 最初に香港でウイルスが分離さ れましたけれどもほほ同時期に米国 CDCでもコロナ ウイルスを検出しており，その後 WHO ネットワーク によって両者が同一の新型コロナウイルスであること が確認されました. このコロナウイルスは, PCRでも 咽頭，便などから $100 \%$ 近く検出できている. 電顕で もみつかり，血清抗体でもこのウイルスに対する seroconversion が起こる.これは全部の関係国で陽性に出 ております。一方，ある病原体が，ある感染症の原因 であるかどうかということを考える際には，コッホの 三原則が非常に役に立つのですが，ウイルスの場合に は必ずしもコッホの三原則が適応できない.ウイルス は不顕性感染もあるし, 持続感染もある. 腫瘍ウイル
スのように hit and runをして, 病気が起こった時はウ イルスが見つからないという様なものがあるので, 必 ずしも適応できないわけですが，一応，これに照らし 合わせて, このメタニューモゥイルスとコロナウイル スを比べてみますと, メタニューモウイルスというの は, ヒトで頻繁に上気道炎を起こしているウイルスで, 成人になるとほほ $100 \%$ 抗体を持っている．また再感 染も起り, しばしばウイルスは検出される一方, 新し いコロナウイルスについては, SARS でないヒトから は全く検出できていません。それから流行地域でない ところでは, 抗体保有率は 0 である.SARS の患者から は, PCR の感度の問題もありますが, ほほ $80 \%$ 以上陽 性に出てきております。また動物実験ですが，オラン ダで行われた実験の成績です.カニクイザルに SARS コロナウイルスを経鼻感染させると 2 週間後に間質性 肺炎に似た病理所見が出てきて, 咽頭と便からウイル スが回収されました。一方, メ夕ニューモウイルスに ついては，殆ど何も病気を起こしてこなかった．この ことから WHO のネットワークでは, 4 月 16 日にこの 3 つの条件 (これだけではありませんが) を満たすもの と判断し, 新型のコロナウイルスが SARS の原因の病 原体であると同定致しました。以上です. 


\section{臨床像 \\ 杏林大学医学部感染症学 \\ 小林治}

(スライド 1$)$

杏林大学感染症学教室がこの 4 月に設立されまし て，それに関連して，まずSARS 対策を視察する目的 で香港へ行ってまいりました。そこで，本日はSARS の臨床像についてお話させていただきます.

(スライド 2)

まずSARSの一般的な認識から括話しさせていた だきます. SARS コロナウイルスの関連した感染症で はないかということ, 病原体の消毒抵抗性はエ夕ノー ルや次亜塩素酸ナトリウムで消毒される，いわゆる消 毒抵抗性が低いという事がありますが，一方では感染 伝播が強く，アジア地区を中心に世界的な流行をして いる，好発年齢が働き盛りである，潜伏期間は 2 日か ら 10 日間である。自然寛解率は $80 \%$ とかなり高いの ですが，死亡率は統計によるようですので当初 $4 \%$ だったものが 10\%から 15\%であるといわれておりま す.しばしば病勢が急速に進行して，この病原体には 有効な治療薬がまだ判明していない。この様なことが あるにもかかわらず，未だ日本においては確定例は無 いということでございますので, 私どもにはSARS について考える時間を与えられているわけでありま す.

(スライド 3$)$

先ほど講演された照屋先生からいただいたスライド ですが, SARS の可能性例の累積発生状況です. 黄色で 示しましたべトナムは上手く終息されたわけですが, 同時多発的に市中及び院内で SARS の流行が起こっ た香港においては, 殆どうなぎ上りに上昇していった。

(スライド 4)

私が視察しましたところは, 香港大学附属 Queen Mary Hospital であります. 丘の上の非常に綺麗な病 院であります。これは病院の昼間の風景ですが, どう も人がいないじゃないかということが窅えるのは,こ の病院の中で, すでに SARSの患者さんがいらしゃっ て，面会の制限がされているからであります.

(スライド 5$)$

この施設では, Kenneth W. Tsang 教授ならびに
Wah K. Lam 教授，このグループが逸早くSARS の詳 細な臨床的検討を The New England Journal of Medicine に報告したという事例がありましたので，実情を 詳しく伺ったのであります。

(スライド 6)

その Lam 教授らがまとめられた SARS 症例の初発 症状のまとめであります. $38^{\circ} \mathrm{C}$ 以上の発熱は必発であ ります。しかしながら，考えてみれば SARS というよ うなものを,私どもは $38^{\circ} \mathrm{C}$ 以上の急な発熱ということ で括っておりますので，これは当然といえば当然であ ります．本日，いろいろお話がありますが，熱が無い SARS があるかもしれない, あるいは感染伝播をさせ るような人がいるかもしれないということでありま す. 悪寒は $73 \%$, 筋肉痛 $60 \%$, 乾燥咳 $57 \%$, 頭痛は 55\%，きわめてインフルエンザに類似しているという 特徴があります。一方で, 喀痰は $29 \%$, 下痢は香港全 体で見ると $20 \%$ ということでありましたが, 後々の報 告によりますと, 例のマンションでの, 岡部先生から の報告がありましたが, 縦方向の感染伝播のあった群 を抽出いたしますと,下痢の症状は $60 \%$ 程度と伺って おります．特徵とすべきは，咽頭痛の頻度は極めて低 いということ，上気道感染を思わせるような症状は極 めて少ないということであります．注意しなくてはい けないのは, 低酸素血症とは必ずしも初期から出現す るものではないのだということであります．発熱があ る, 悪寒がある, こういったこと, 加えて私ども日本 においては感染伝播地域からの帰国ということで SARS の疑いができるわけですけれども, $\mathrm{SpO}_{2}$ が低く ないからこれは違うのではないかということは, 判断 に誤りを及ぼす可能性があるということであります。

(スライド 7)

血液検査でございます．負血はございません．白血 球は通常は正常でございますが, 白血球数が 2 万程度 まで上昇したSARSの報告も散見はされております。 特徵的なのはリンパ球の減少が見られているというこ とです. 血小板, これに関しましては, 中国本土のデー ターを加味しますと滅少することが多いとされており 
ますが，香港ではそれほど頻度は高くないといわれて おります. 生化学的検查です. Creatinine は正常, GOT, GPT, これはしばしば増加するということがい われています。CPK，これに関しましても悪寒や多臓 器不全に関連して，中国本土によりますと頻度が高い と報告されておりますが, 香港のデーターからすると， それほど頻度は高くないといわれています。

(スライド 8$)$

胸部 X 線所見です．異常所見は通常，下肺野から広 がります．胸水を伴わないことが特徴とされておりま す。急速な異常㓌影の進展がみられますので，1日に 2 回の X 線撮影が推奨されています.

(スライド 9)

SARS 剖検 6 例についても，すでに Lancet に掲載さ れております。リンパ球を主体とした diffuse alveolar damageは，全例に見られております。このような ARDSの病態はウイルス血症による直接的なもので はなく，むしろ腸管内などでも増殖したSARS コロナ ウイルスに対する cytokine stormによる過剩免疫反 応としてとられる向きもあります。一方でウイルス感 染を示唆するような，巨細胞化も，全 6 例中 4 例にみ られております，注目すべきところは，BOOP 様変化 はしばしば散見されるということであります。これは 実際にQueen Mary Hospital の先生方もしばしば BOOP 様の病態が見られるのだといわれていました. 一方で，フィブリン血栓のような，こういった全身性 の過剩炎症反応，DIC が見られる所見は珍しいとのこ とであります.

(スライド 10)

実際にQueen Mary Hospital が行なっていた SARS 疑い症例に関するルーチン検査であります。CT 検査 を行なわないとしておりましたのは，一つは感染伝播 を蔓延させやすい可能性があるからで，もう一つは医 療経済的な問題からだったのですが，日本においては お金の問題さえ解決できれば，レントゲンに比して CT は，異常陰影が数日早く出現する傾向が見られる ようであります，そのことを考えますと，香港の先生 方は,でき机ば日本に拝いては, CT 検查はルーチンで やった方がいいのではないかといっておられました. 実際，一般の患者さんと SARS の関連した疑い例とを 同じ CT 室内で検査を行うことは感染防等の点から難 しいので，隔離した施設で $\mathrm{CT}$ 検査を行なえるような 施設というようなことが条件としてあがってくるかと 思います.Queen Mary Hospitalにおいては, 市中肺炎
との鑑別との目的で，血液抢よび尿培，喀痰培養，血 清マイコプラズマ, クラミジア，レジオネラの抗体検 査，尿中レジオネラ，尿中の肺炎球菌の抗原の検査と いうものを徹底的に行なっております。コロナウイル 久検出の目的の検査をすると同時に, 経過観察目的で, 血算，血沈，生化学，血糖， $\mathrm{CRP}$ 等々を行なうという ことは，私どもがもし SARS を帱見するにあたっても 同じょうなことをするのではないかと思っておりま す.

(スライド 11)

さて, Queen Mary Hospital におけるSARS 可能性 例の治療の例であります。いわゆる香港において発熱 があって, 呼吸器の症状があり, 加えてレントゲンで 肺炎像がある場合には，SARS の可能性例が極めて高

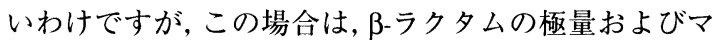
クロライド系の治療，すなわち市中肺炎，あるいは非 定型肺炎の鑑別の目的で，empiricに maximum dose の治療を行なう。もしくは, - -ラクタムにアレルギーが ある場合に限っては，香港においてはレボフロキサシ ンの点滴薬剤があるので，これを用いると伺っており ます．先ほどの治療法を名付けて big gun antibiotics 療法というそうでありますが，まず入院して肺炎病棟 で行ないます。そこでもし反応がなかった場合には， あるいは増悪傾向が見られた場合には，これは極めて SARS の疑いが濃厚であり, SARS-ICU 病棟という隔 離された陰圧室での集団隔離を行うのです。

(スライド 12)

この場合，彼等はステロイド大量療法および，本邦 に抢いては C 型肝炎の治療薬として用いられている ribavirin を用いると聞きました。ステロイドの具体例 ですが, methylprednisolone 500mg を5 日間というよ うな治療を，ひとつ標準としているそうです，先ほど のリンパ球を主体としたARDS，これが恐らく SARS の死因の最も代表的なものであると考えますと，その 生命予後を改善させる目的で, 初期からのステロイド 療法は，私見ですが有効だと考えます。一方で，この ribavirin は，かなり doseが高いです．本邦において ribavirinは，カプセル用片しかございません，そう いった事情も考えまして,さらに保険医療との関連で, 実際このSARS コロナウイルスに対して ribavirin の 効果は試験管内ではみられない。一方で, 臨床的な効 果は見られたと香港はいっていますが，そのことをよ く考虑しながら今後は対策を練る必要があると思って おります。 
(スライド 13)

大変重要なことがひとつ, $\mathrm{BiPAP} / \mathrm{CPAP}$ おびネ ブライザーは絶対に用いないでくれと言われていま す。今まで私ども色々調べてみましても，BiPAP/ CPAP あるいはネブライザーに関連して呼吸器感染症 等々が蔓延したという報告は無かったと思います。し かし, 今回に限っては BiPAP/CPAPを使った患者さ ん，特に加えてネブライザーを使った患者さんの周辺 でスタッフの感染頻度が極めて高かったという報告が 見られております．特に BiPAP/CPAP が苦しくて自 己抜去してしまったという症例に関して，咳嗽反射に 乗ってウイルスが散布され，そして感染伝播した可能 性が高いと考えたので, Queen Mary Hospital では一 般病棟における BiPAP/CPAP およびネブライザー使 用は基本的に禁止しておりました。これは香港での失 敗の事なので，日本の皆さんに是非伝えて欲しいと言 われて来ました。

(スライド 14)

実際の症例を呈示致します５0 歳の男性で，SARS の可能性例としてICUに入院中であった叔父さんを 頻繁に見舞っていた方であります。急速に進行する発 熱, 悪寒を主訴に来院. Queen Mary Hospital の肺炎病 棟に入院したと言うことであります，第 2 病日には， 胸部 X 線上で左下肺から急速に進行する浸潤性侩影 が観察されました。貧血は無く，白血球はやや低い， 血小板は 16.1 万, リンパ球は 1300 と減少し, GOT/ GPT は $96 / 58$ と上昇傾向がみられております。

\section{(スライド 15)}

胸部 X 線です. 第 1 病日には左肺に限局していたス リガラス状の陰影が少し第 2 病日には広がってまいり ました。

(スライド 16)

big gun antibiotic 療法，すなわち $\beta$-ラク夕ムの極量 およびマクロライドに反応性不良ということで即座に この患者さんは ICUの SARS 専用の陰圧室に移され ました.そこでステロイドおよび ribavirin の治療を行 なったわけであります。体温です、ステロイドの影響 と思われますが, $38^{\circ} \mathrm{C}$ 以上あった熱が, 翌日には急速 に下がり， $37^{\circ} \mathrm{C}$ 台となっております。解熱に伴いまし て, 脈拍数が 95〜 7 位から 85 位までに下がっておりま す. $\mathrm{SpO}_{2}$ の改善は暫くは見られません. 白血球数です が, 当初 6,000 程度だったのですが, おそらくステロイ ドの影響で, day3には11,000 程度まであがっており ます. 注目すべきリンパ球ですが, その後下がって 800
位になった，それがなかなか改善の見込みがなかった が day7, day8 あたりから少しずつあがって, 900 位ま であがりました．血小板数については，20万から 30 万を前後しております．決してそれほど低い数值だと は言えないと思います。これが SARS の典型的な経過 であると教わってまいりました.

(スライド 17)

この症例 1 から学ぶ点は, ribavirinは果たして SARS に対する臨床的効果があると言えるのか.もし かしたら今の治療の本質というのは, 治療の改善効果 というのは，ステロイドの効果といえるかもしれませ ん.しかしながら， ribavirin を使ったからいいのだと 実感をもっている先生もいらしゃいます。この実感を 信じるか信じないかは，個々の主治医の判断によるこ とになるかもしれません. SARS における急性呼吸器 不全に対するステロイドの効果，あるいは用量，投与 期間の問題は，今後考えていかなくてはならないと思 います。こういった ARDSに対するステロイド療法, これは初期のうちから methylpredonisolne 500mg 程 度を数日間投与ののち，急速に斬減する程度がいいの ではないかという実感を私も持っておりますが，実際 の SARS 症例にどのように対応していくかについて は,なかなか難しい問題かもしれません. SARSにおけ る急性呼吸不全の呼吸管理はどうすればいいのか, ARDSにおける呼吸管理で調整を例えば頻呼吸に設 定してしまった場合，あるいは気道内圧を高く設定し てしまった場合，こういった場合，うまくARDSを上 手く沈静化できない症例があるとしばしば聞きます. そういったことを細かくいかに調整していくかが, 我々が事前に考えておかなくてはいけないのではない かと思っております。

(スライド 18)

症例 2, 72 歳の男性. SARS が集団発生した香港のホ テルに宿泊しました。発熱と悪寒を主訴に近医に即日 入院となったが，他患および 3 名の看護師が 2 日の間 に同様の症状を訴えたためにQueen Mary Hospital に 転送された。当初は big gun antibiotic 療法により, 症 状，所見とも改善した。しかしながら，その後，呼吸 器不全がもう一度あり，Queen Mary Hospital の SARS 専用 ICU でベンチレーター管理となるが，離脱 したもちろん，この時点でステロイドと ribavirin の治療が行なわれたということです，症状，所見とも 改善された時点で, 元の近医に転送して完全寛解の後, 改めて SARS のコロナウイルスが検出され, 確定診断 
されたという症例であります。

(スライド 19)

さて, この症例, 経過中, 2 回の症状所見の悪化が見 られております。もしかしたら最初の一波は細菌性肺 炎を合併したもので単純にそれに対して抗菌療法が効 いたのかもしれません．しかしながら，それとは全く 無関係で, 抗生物質の効果は全く関係なく, 経過中, 単にSARS ウイルスの変異が起こったのかもしれま せん，それは全く持って想像の域であります。一方で, 複合的な臨床経過, これこそが SARS の特徵といえる かもしれません.すなわち,増悪寛解を繰り返す SARS 症例が中には潜んでいるかもしれません，示唆的な症 例であります。

(スライド 20)

さて，症例 3 です． 32 歳，女性. 6 日間持続する高 熱，悪寒，乾燥性の咳を主訴に来院しております。こ の方はSARS の疑いまたは可能性例との接触はござ いません。 また, 過去 2 週間 SARS の伝播地域への渡 航歴もございません. 白血球は正常, リンパ球は軽度 減少, GOT, GPT は正常である. 胸部 X 線では, 左下 肺野に肺炎像を認めたということで，先に申し上げま したQueen Mary Hospital の肺炎病棟に入院した症例 であります。

(スライド 21)

強力な抗生物質療法, すなわち big gun antibiotic 療法を開始した結果，24 時間以内に解熱し，3 日で胸 部 $X$ 線所見が改善，一般病棟に格下げになった。さら に 48 時間以内に帰宅して，自宅安静となった理由は， この人が非定型肺炎としての確定診断を得たというこ とだからであります.すなわち, 見方によってはSARS
がどんどん流入しているような場合には，非定型肺炎 の発生と, SARS の発生との鑑別は非常に困難である, ということを示唆する症例であります.

(スライド 22)

SARS 臨床像については，まだまだ不明なところが あります，その診断，治療，管理には慎重を要します。 日本においては，まだ確定例もございませんし，そう いった意味ではSARSのトリアージは，まず感染伝播 地域からの帰国などの詳細な問診が重要であります。 実際，いろいろな施設に伺いますと，白内障の手術で 入院した患者さんが害は 3 日前に感染伝播地域から帰 国者だったということで，病院に入れるかどうかにつ いてもめたような症例もございました. 今, 新たに「詳 細な問診」を見直す時期ではないかと思います。また， 今はインフルエンザの流行時期ではありませんが，初 期症状が極めてインフルエンザに類似しているので, インフルエンザ流行下におけるSARS の即時的な鑑 別診断をいかにすべきか. あるいは今年の冬，もし SARS が流行する可能性があるとすれば，やはりこれ からインフルエンザウイルスを接種するように皆で啓 蒙しなくてはいけないのではないかとも思うのであり ます. 現在, SARS コロナウイルスに対する, 明確な抗 ウイルス剤を有する薬剤は不明ではありますが, SARS コロナウイルスに関連して発症するARDSに 対する治療，具体的には cytokine storm に対するステ ロイドの使用，適切なベンチレーター管理などが，機 能，生命子後を左右するかどうかということは，私ど もは今のところ文献的検討しか知り得ないですが，や はり実際に扯見したら使わざるを得ないかと思われる のが私見であります。御静聴ありがとうございました。 
スライド 1

\section{SARSの臨床像}

杏林大学感染症学

小林 治

\section{SARSの一般的な認識}

- SARS CoV感染症?

- 病原体の消毒抵抗性は低いが感染伝播は強い

・アジア地区を中心に世界的に流行

- 好発年命は30 50歲台

- 潜伏期間は2 10日間

- 自然寛解率は80 90\%

- 死亡率は4 15\% ?

・しばしば病势は急速に悪化する

- 病原体に有効な治療薬は判明していない

・ 未だ日本においては確定例がない
スライド 4

\section{香港大学付属}

Queen Mary Hospital (QMH)

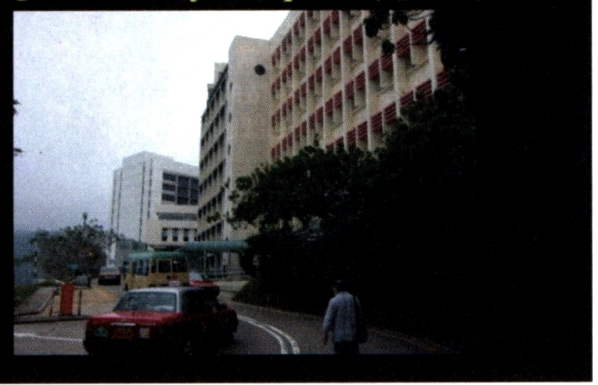

スライド 5
A Cluster of Cases of Severe Acute Respiratory Syndrome in Hong Kong

Kenneth W. Tsang, Wah K. Lam, et al. The New England Journal of Medicine, 2003

$$
\text { スライド } 3
$$

\section{SARS可能性例累積発生状況}

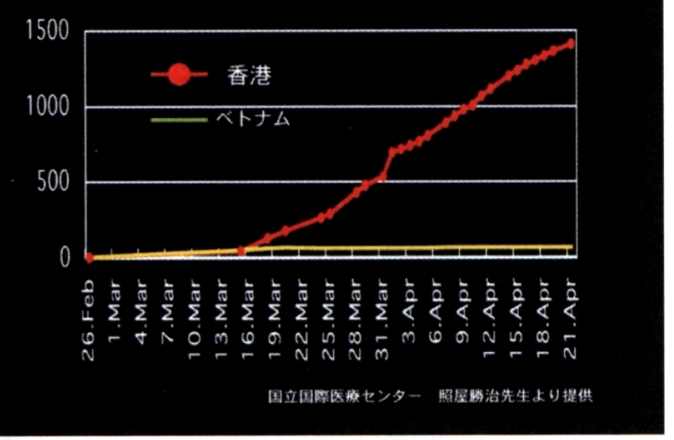

スライド 6

\section{SARSO症状}

- $38^{\circ} \mathrm{C}$ 以上の発熱 $(100 \%)$

- 悪寒 $(73.2 \%)$

- 筋肉痛 $(60.9 \%)$

- 乾性咳 $(57.3 \%)$ - やや遅れて出現

- 頭痛 $(55.8 \%)$

極めてインフルエンザに類似している

- 喀痰 $(29 \%)$

- 下廄 $(20 \%)$

- 咽頭痛 - 頻度は低い

... 低酸素血症は必ずしも初期に出現しない 


\section{血液検査}

- 血算

-ヘモグロピン......通常正常

白血球数............通常正常

リンパ球減少......特微的所見

血小板.

..しばしば侙少

- 生化学

Creatinine.........正常

AST(GOT)とALT(GPT)......しばしば増加

CPK. 稀に増加
SARS疑い症例に対するルーチン検査 (QMH)

- C下検査は行わない

・市中肺炎との籃別の目的 C

血液およU尿培共

喀疼培養

血清マイコフラスマ、クラミジアレジオネラ抗体换榃

尿中レジオネラ.肺资球菌抗原搤直

- コロナウイルス検出の目的で

鼻腔およひ咽頚スワプのPCR検榃

血清IgMおよU゙IgG

- 経洞䘽察

血算、血沈、血清生化学、血制

CRP

T4. TSH
スライド 8

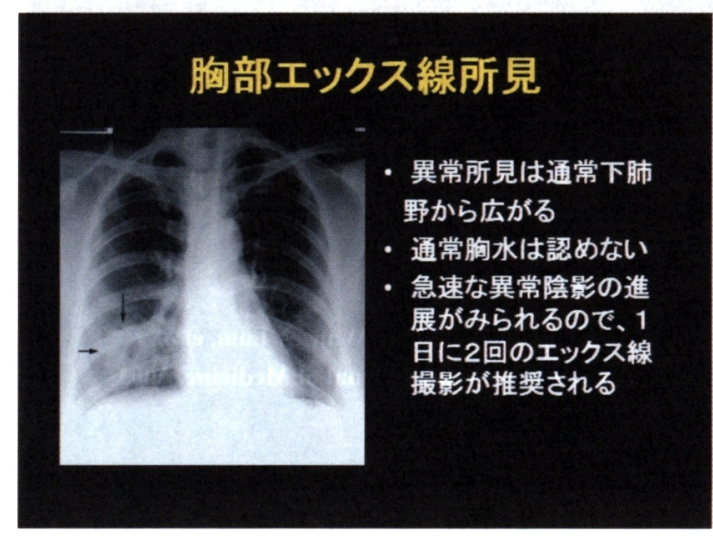

スライド 9

\section{SARS剖検6例についてのまとめ}

\begin{tabular}{|c|c|c|c|c|c|c|c|}
\hline \multirow[b]{2}{*}{ 性别 } & \multicolumn{7}{|c|}{ SARS剖検6例についてのまとめ } \\
\hline & 年齢 & $\begin{array}{l}\text { 発福から } \\
\text { 人院まと }\end{array}$ & 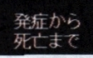 & $\mathrm{DAD}$ & 巨細胞化 & $\begin{array}{l}\text { その他の } \\
\text { 組藏所見 } \\
\end{array}$ & 基碮疾䓌 \\
\hline 女 & 37 & 10日 & 20日 & $(+)$ & $(-)$ & 肺胞上皮破壊 & $(-)$ \\
\hline 女 & 39 & 3日 & 8日 & $(+)$ & $(-)$ & 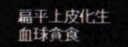 & $(-)$ \\
\hline 男 & 64 & 7日 & 17日 & $(+)$ & $(++)$ & 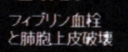 & $(-)$ \\
\hline 男 & 53 & 5日 & 24日 & $(+)$ & $(++)$ & BOOP㮞变化 & 高血圧 \\
\hline 男 & 49 & 9日 & 17日 & $(+)$ & $(++)$ & 肺絇上皮破填 & 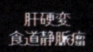 \\
\hline 男 & 77 & 2日 & 16日 & $(+)$ & $(++)$ & & $(-)$ \\
\hline
\end{tabular}

Nicholls JM, Poon LI, et al, THE LANCET, Published online May 16, 2003 http://innage. thelancet.com/extras 03 art 4347 web.pdf
スライド 11

\section{SARS可能性例の治療(QMH)}

- SARSに合併した市中肺焱の治療

・発熱の軽娍と胸部エックス線所見の改善を期待 した [big gun antibiotics] 治療老行う

- [big gun antibiotics]とは広域スペクトルの抗菌 療法であり、具体的には

- I.V. Rocephin 1g Q24h, or Tazocin 4.5g Q8h or Maxipime $2 \mathrm{~g} \mathrm{Q8h}$

- (I.V. Levofloxacin $\mathbf{5 0 0} \mathrm{mg}$ daily if allergic to penicillin)

- P.O. Clarithromycin 500 mg B.D.

\section{スライド 12}

\section{Big gun antibioticsが無効な場合}

ステロイド大量療法およびリハピ゙リンが用いられる

- I.

- IV MP $500 \mathrm{mg} /$ day $x 5$ days

- Oral prednisolone

- I.

- Hydrocortisone $2 \mathrm{mg} / \mathrm{kg}$ Q6h or $4 \mathrm{mg} / \mathrm{kg}$ Q8h I.V

- Ribavirin $8 \mathrm{mg} / \mathrm{kg}$ Q8h I.V.

- II.

- IV MP $3 \mathrm{mg} / \mathrm{kg} /$ day $\mathrm{x} 5$ days, then

$-2 \mathrm{mg} / \mathrm{kg} /$ day $x 5$ days, then

$-1 \mathrm{mg} / \mathrm{kg} /$ day $x 5$ days, then

- Oral prednisolone to tail off in 6 days 
スライド 13

BiPAP/CPAP およびネブライザーは 絶対に用いない!

・ BiPAP/CPAPおよU゙ネブラーザーはウイルス の空気中への散布を助長している可能性が 示豀されている

・ 以上の理由から、QMH では一般病棟におけ るBiPAP/CPAPおよびネブライザーの使用を 基本的に禁止している。
スライド 16

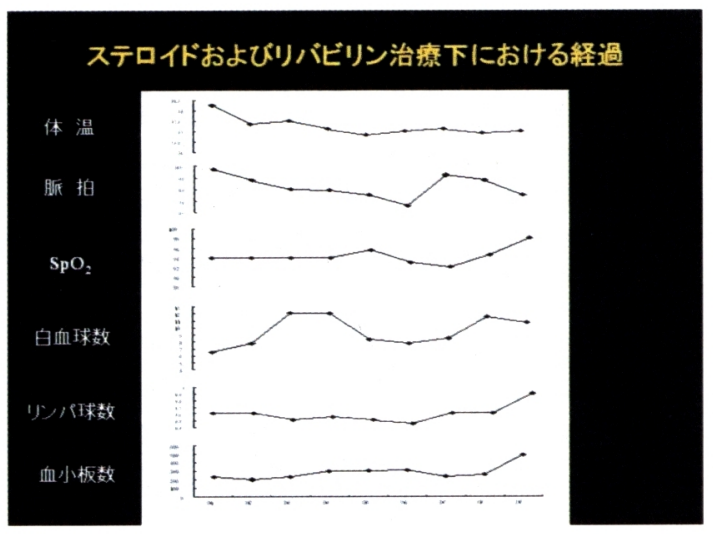

スライド 17

- SARS可能性例としてICUに入院中であつた叔父を類䇣 に見舞っていた

- 急速に進行する発熱と亜寒圭主訴に来院

- QMHの肺炎病棟に入院

- 第2病日には胸部エックス缐上で左下肺野から急速に進 行する浸洞性院影が钼察された

- 血液唡査所見

Hb 14.2, WBC 3.2, platelet 16.1

Lymphopenia 1.3

AST/ALT 96/58

スライド 15

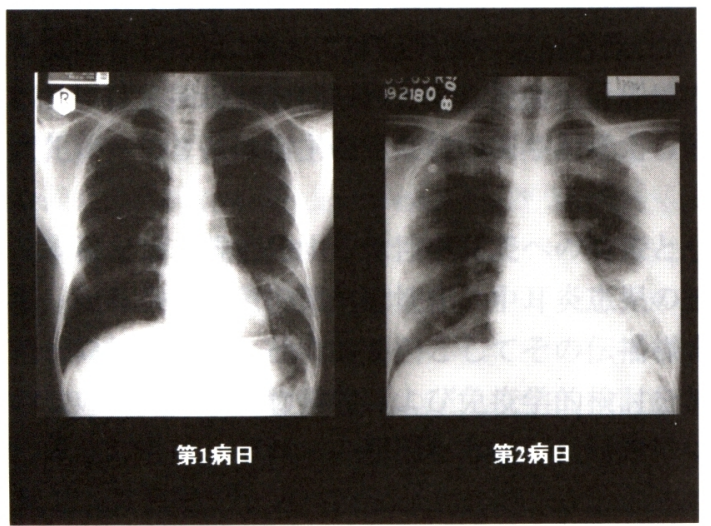

\section{スライド 18}

\section{症例 2:72歳男性}

- 生来健康

・SARSが集団発生した香港のホテルに宿泊

- 発熱之悪寒圭主訴に近医壱受診

・近医に即日入院となつたが他患および3名の看護師が2 日の間に同様の症状寺訴えた

- この時点でQMHに転送の結果、発熱と胸部エックス缐 上の肺咨像からSARS可能性例と判断され、まずは診断 的治庱として強力な抗生物筫癔法寺行われた結果、症 状所見ともに改善した。

- その後、呼吸不全が悪化し、QMH内のSARS専用ICU にて一時人工呼吸器管理となるも離脱

- 症状斥見共に改善した時点でもとの近医に転送

・完全寛解ののち、SARSと確定診斦された 


$$
\text { スライド } 19
$$

\section{症例2 の特異な経過}

経過中2回の症状所見の悪化がみられた

1) 当初は細菌性肺焱が合併したか?

2)または経過中にSARSウイルスの変異 が起こつたのか?

3) 複合的な臨床経過はSARSの特徴とい えるのか?

$$
\text { スライド } 21
$$

\section{症例 3 の経過}

強力な抗生物質療法を開始した結果 ...

-24時間以内に発熱が改善

・3日間で胸部エックス線所見が改善

・一般病楝に「格下げ」

-48時間以内に帰宅し自宅安静

・その後、非定型肺焱の確定診断を得た

\section{スライド 20}

\section{症例 $3: 32$ 歳女性}

- 6 日間持続寸る高熱、悪寒、乾焻性咳走主訴に来院

- SARS関連志わせる要因なし

一SARS疑いまたは可能性例との接蚛

過去14日間,SARS伝播確認地域への渡航歴(香港内 での危険区域走含む）

- 血液検査所見

白血球数正常

軽度リンハ球数慽少

GOT, GPT正常

- 胸部エックス缐では左下肺野に肺炎像を䜑める

- QMHの肺焱病棟に入院

\section{スライド 22}

$$
\text { まとめ }
$$

- SARSの臨床像については不明な点が多く、そ の診断／治療／管理には慎重を有する

・日本におけるSARSのトリアージはまず感染伝播 地域からの帰国など詳細な問診が重要

・ 今後インフルエンザ流行下におけるSARSの即 時的な鑑別診断はいかにすべきか?

- 現在,SARS-CoVに対する明確な抗ウイルス作 用を有する薬剤は不明であるが、SARS-CoVに 関連して発症するARDSに二対する治療(Cytokine stormlに対するステロイドの使用、適切なベンチ レータ管理など)が機能／生命予後を左右する? 